التوزيع الأمثل لإنتاج محصولي البرتقال والبصل بين المحافظات المصرية باستخدام نماذج النقل

$$
\text { فيروز أحمد عبد المالك أحمد وسحر سعيد يعقوب محمد } 1
$$

448.3 ألف طن يمثل نحو 98.6\% من جملة الفائض لمحافظة الإسماعيلية. كما يتم توزيع الفائض لمحافظة السويس والبالغ حوالي 21.5 ألف طن إلى محافظة جنوب سيناء بكمية تبلغ حوالي 0.4 ألف طن بنسبة تمثل نحو 1.9\% من جملة الفائض

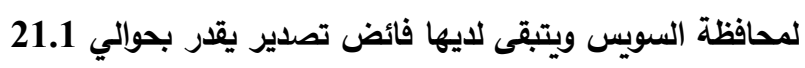
ألف طن يمثل نحو 98.1\% من جملة الفائض بها. وأيضا يتم

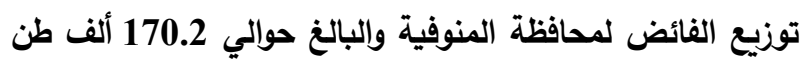

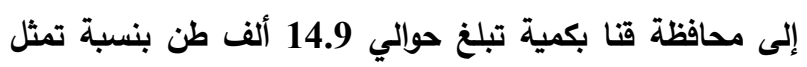

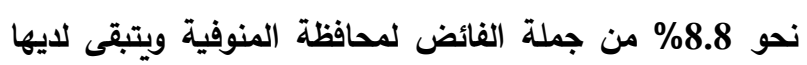

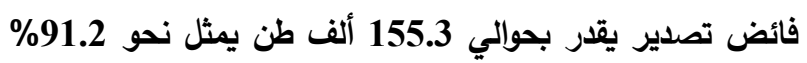

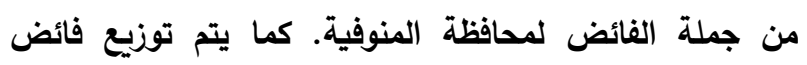
محافظة القليوبية والبالغ حوالي 262.6 ألف طن إلى محافظات

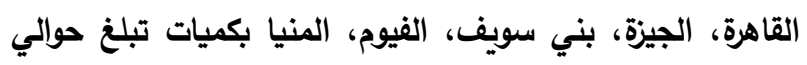
79.7، 30، 6.1، 26، 40.3 ألف طن على الترتيب تمثل نحو

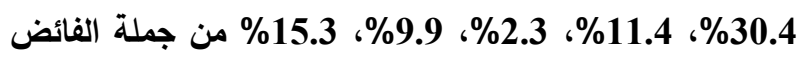
لمحافظة القليوبية على الترتيب ويتبقى لايها فائض تصدير يقدر بحوالي 80.5 ألف طن يمثل نحو 30.7\% من جملة الفائض لمحافظة القليوبية. كما يتم توزيع الفائض لمحافظة أسيوط والبالغ حوالي 44.6 ألف طن إلى محافظات سوهاج، قنا بكميات

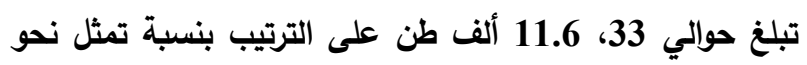
74\%، 26\% لكل منهما على الترتيب من جملة الفائض

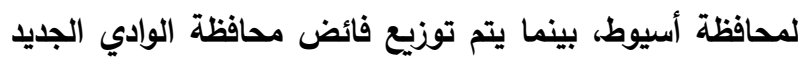
والبالغ حوالي 20.3 ألف طن إلى محافظات سوهاج، الأقصر ،

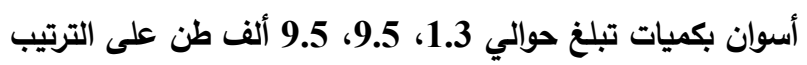
تمثل نحو 6.4\%، 46.8\%، 46.8\% من جملة الفائض لمحافظة

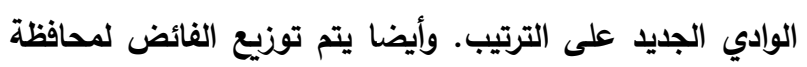

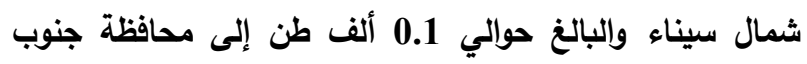
سيناء بكمية تبلغ حوالي 0.1 ألف طن بنسبة تمثل نحو 100 الفياء

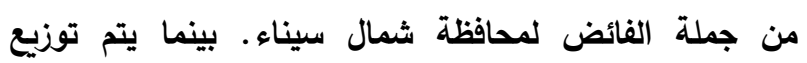
الفائض لمنطقة النوبارية والبالغ حوالي 723.6 ألف طن إلى لى

$$
\text { الملخص العربى }
$$

استهاف البحث بصفة رئيسية تدنية تكاليف النقل

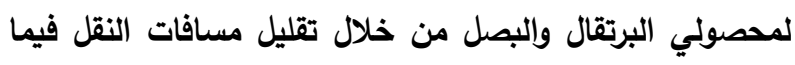

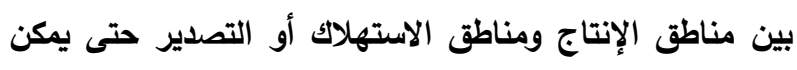

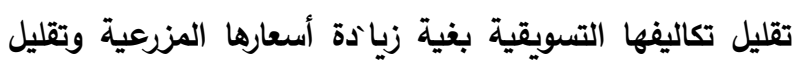
أسعار المستهكين لها بالإضافة إلى تقليل تكاليفها التصديرية إستناداً إلى نتائج نموذج النقل من خلالال أسلوب البرمجة البعائ

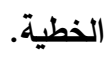

ويتضح من نتائج التوزيع الأمثل للفائض من البرتقال

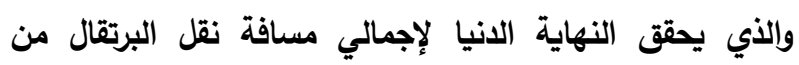

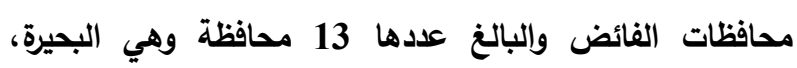
الغربية، كفر الثيح، الثرقية، الإسماعيلية، السويس، المنوفية،

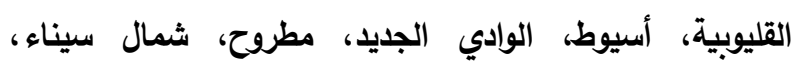

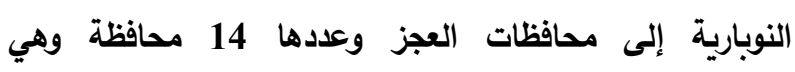
الإسكندرية، الدقهلية، دمياط، بور سعيد، القاهرة، الجيزة، بني

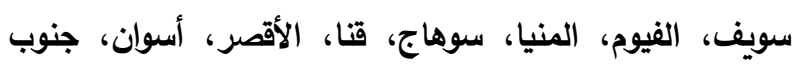
سيناء . سوبف، أل

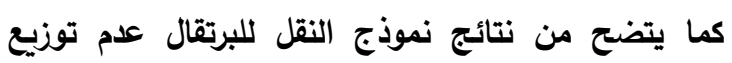
الفائض من البرتقال لكل من محافظات البحيرة، كفر الثيخ،

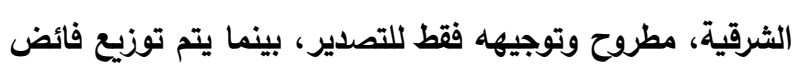

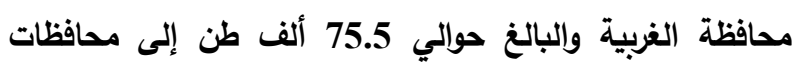

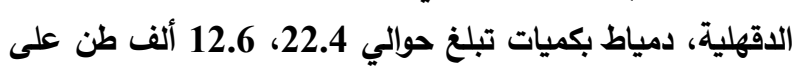

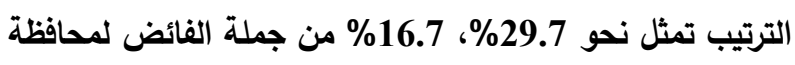

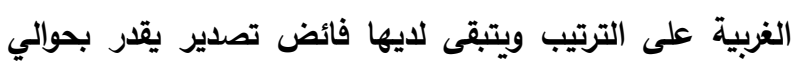
40.5 ألف طن يمثل نحو 53.6\% من جملة الفائض لمحافظة الغربية. بينما يتم توزيع الفائض لمحافظة الإسماعيلية والبالغ حوالي 454.5 ألف طن إلى محافظة بورسعيد بكمية تبلغ حوالي 6.2 ألف طن بنسبة تمثل نحو 1.4\% من جملة الفائض لمحافظة الإسماعيلية ويتبقى لديها فائض تصدير يقدر بحوالي 1 قسم الاقتصاد والإرشاد الزراعي والتتمية الريفية . كلية الزراعة ـ جامعة دمنهور

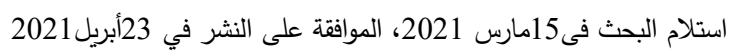


إلى محافظات الإسماعيلية، بورسعيد، القاهرة، شمال سيناء بكمية تبلغ حوالي 19.98، 10.8، 28.9،

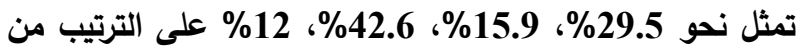
جملة الفائض لمحافظة الثرقية ولا يتبقى لايها فائض للتصدير. وأيضا يتم توزيع الفائض لمحافظة القليوبية والبالغ حوالي 66.07 ألف طن إلى محافظة الجيزة بكمية تبلغ حوالي نكابع ألف طن بنسبة تمثل نحو100\% من جملة الفائض لمحافظة القليوبية. كما يتم توزيع فائض محافظة بني سويف والبالغ حوالي 96 ألف طن إلى محافظة المنيا بكمية تبلغ حوالي 24.02 ألف طن تمثل نحو 25\% من جملة الفائض لمحافظة بني سويف ويتبقى لايها فائض تصدير يقدر بحوالي 71.98 ألف طن يمثل نحو 75\% من جملة الفائض لمحافظة بني سويف. كما يتم توزيع الفائض لمحافظة الفيوم والبالغ حوالي 84.38 ألف طن إلى محافظة الجيزة بكمية تبلغ حوالي 70.1 ألف طن بنسبة تمثل نحو 83\% من جملة الفائض لمحافظة الفيوم ويتبقى لليها فائض تصدير يقدر بحوالي 14.37 ألف طن يمثل نحو 17\% من جملة الفائض لمحافظة الفيوم، بينما يتم توزيع فائض محافظة لهن سوهاج والبالغ حوالي 164.16 ألف طن إلى محافظات أسيوط، الأقصر، أسوان، جنوب سيناء بكميات تبلغ حوالي 38.1،

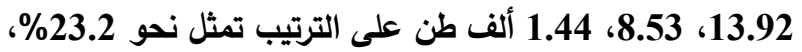

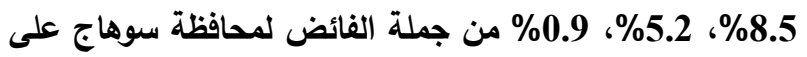
الترتيب، ويتبقى لايها فائض تصدير يقدر بحوالي 102.17 ألف عن جمانه طن يمثل نحو 62.2\% من جملة الفائض لمحافظة سوهاج. وأيضا يتم توزيع الفائض لمحافظة قنا والبالغ حوالي 0.38 ألف هن طن إلى محافظة قنا بنسبة تمثل نحو 100\% من جملة الفائض

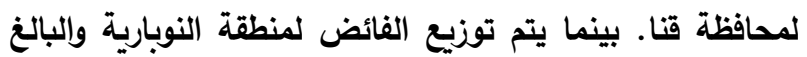
حوالي 212.47 ألف طن إلى محافظات الإسكندرية، مطروح بكميات تبلغ حوالي 94.2، 1.92 ألف طن بنسبة تمثل نحو 44.3\% 0.9\% من جملة الفائض لمنطقة النوبارية ويتبقى لايها فائض تصدير يقدر بحوالي 116.35 ألف طن يمثل نحو 54.8 من جملة الفائض لمنطقة النوبارية. وتثير نتائج نموذج النقل أيضا إلى أنه تم زيادة كمية الصادرات من البصل من 444.67 ألف طن إلى حوالي 1033.53 ألف طن أي بزيادة قدرها 588.86 ألف طن تمثل نحو
محافظة الإسكندرية بكمية تبلغ حوالي 36.6 ألف طن بنسبة تمثل نحو 5.1\% من جملة الفائض لمنطقة النوبارية ويتبقى لايها فائض تصدير يقدر بحوالي 687 ألف طن يمثل نحو \%94.9 من جملة الفائض لمنطقة النوبارية. وأثثارت نتائج نموذج النقل لمحصول البرتقال إلى أنه تم زيادة كمية الصادرات من البرتقال من 1647 ألف طن إلى حوالي

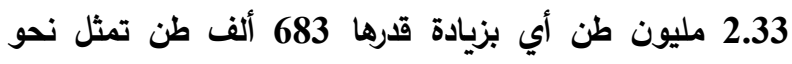
\%41.5 من متوسط كمية الصادرات من البرتقال خلال فترة الاراسة وبالتالي فإن إعادة توزيع البرتقال بين مناطق ومحافظات الجمهورية يؤدي إلى تقليل الفاقد وكذلك زيادة الصادرات وتقليل العجز في ميزان المدفوعات. وتوضح نتائج التوزيع الأمثل للفائض من البصل والذي يحقق النهاية الانيا لإجمالي مسافة نقل البصل من محافظات الفائض والبالغ عددها 11 محافظة وهي البحيرة، الغربية، الاقهلية، الثرقية، القليوبية، بني سويف، الفيوم، سوهاج، قنا، الوادي الجديد، النوبارية إلى محافظات العجز والبالغ عددها 16

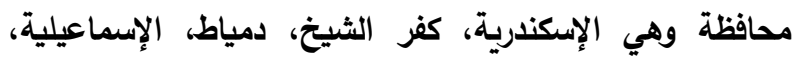
بورسعيد، السويس، المنوفية، القاهرة، الجيزة، المنيا، أسيوط، الإسكيه، الأقصر، أسوان، مطروح، شمال سيناء، جنوب سيناء. وتثير نتائج نموذج النقل للبصل إلى عدم توزيع الفائض من البصل لكل من محافظات البحيرة، الوادي الجديد، وتوجيهه فقط للتصدير، بينما يتم توزيع فائض محافظة الغربية والبالغ حوالي 676.38 ألف طن إلى محافظات كفر الثيخ، السويس، المنوفية، القاهرة بكميات تبلغ حوالي 147.8 ألف طن على الترتيب تمثل نحو 5.3\% \% \% 1.4، \%9.6\% 21.9\% من جملة الفائض لمحافظة الغربية على الترتيب ويتبقى لايها فائض تصدير يقدر بحوالي 418.5 ألف طن يمثل نحو 61.9\% من جملة الفائض لمحافظة الغربية. بينما يتم توزيع الفائض لمحافظة الدقهلية والبالغ حوالي 209.9 ألف طن إلى محافظة دمياط بكمية تبلغ حوالي 4.9 ألف طن بنسبة تمثل نحو 2.3\% من جملة الفائض لمحافظة الدقهلية

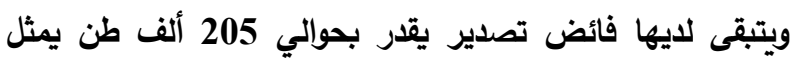

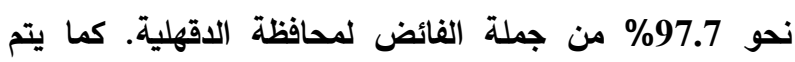
توزيع الفائض لمحافظة الشرقية والبالغ حوالي 67.79 ألف طن 
969 فيروز أحمد عبد المالك أحمد وسحر سعيد يعقوب محمد: التوزيع الأمثل لإنتاج محصولي البرتقال والبصل .......

وخفض تكاليفه وهو ما يعد مساهمة حقيقية في زيادة دخل الزراع وخفض أسعار المستهلكين للسلع الزراعية. ويتسم محصولي البرتقال والبصل بأنهما من محاصيل

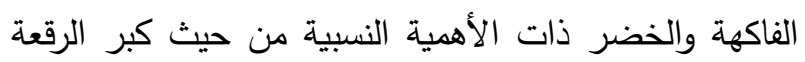
المزروعة بكل منهما و حجم المعروض منهما لأغراض الاستهلاك المحلي والتصدير وفي ذات الوقت تمركز إنتاج كل منهما في عدد محدود من المحافظات حيث بلغت الرقعة المزروعة بالبرتقال المثمر خلال متوسط الفترة (20172019) حوالي 306.7 ألف فدان تمثل نحو 20.7\% من إجمالي مساحة مختلف أنواع الفاكهة(8) كما بلغ إنتاج البرتقال

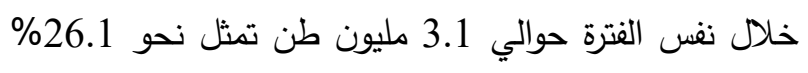
من إجمالي إنتاج مختلف أنواع الفاكهة، كما بلغت كمية

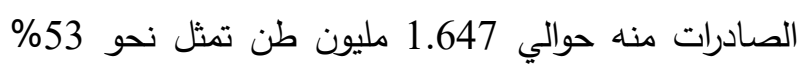
من إجمالي إنتاجه خلال متوسط الفترة سالفة الذكر (7). كما يتمركز إنتاجه في كل من منطقة النوبارية ومحافظات البحيرة، والاسماعيلية، القليوبية، الثرقية بأهمية نسبية بلغت نحو 23.4\%؛ 21.5\%، 14.7\%، 10\% 9.8\% لكل منها على الترتيب وبإجمالي أهمية نسبية لتلك المناطق بلغت نحو 79.4\% من إجمالي إنتاج الجمهورية خلال متوسط الفترة (2017-2019). كما بلغت الرقعة المزروعة بالبصل حوالي 188.34 ألف فدان تمثل نحو 10\% من إجمالي المساحة المزروعة بمختلف أنواع الخضر خلال متوسط الفترة (2017-2019)،

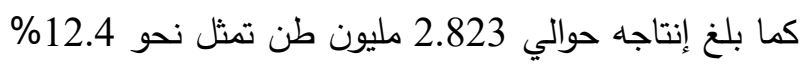

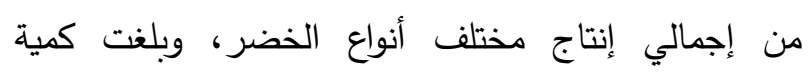
صادراته حوالي 642.7 ألف طن تمثل حوالي 23\% من إنتاجه خلال نفس الفترة سالفة الذكر، ويتركز إنتاجه في

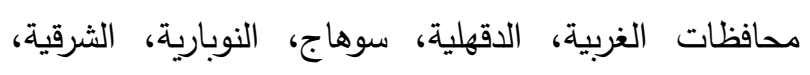
البحيرة، بني سويف، الفيوم بأهمية نسبية بلغت نحوة

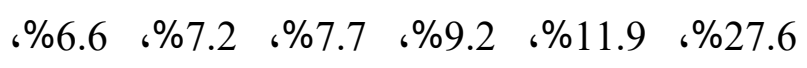

57 من متوسط كمية الصادرات من البصل خلال فترة الدراسة

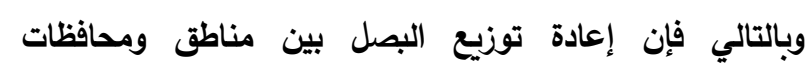
الجمهورية يؤدي إلى زيادة الصادرات وتقليل العجز في ميزان

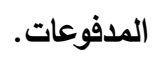

الكلمات المفتاحية: التوزيع الأمثل، الفائض والعجز، محصولي البرتقال والبصل، نموذج النقل. المقدمة

تعتبر كيفية توزيع أو توجيه السلع الزراعية بين مختلف الأسواق من المشاكل النمطية التي تواجه المنتجين ورجال التسويق الزراعي، حيث من المعروف أن العلاقات السعرية

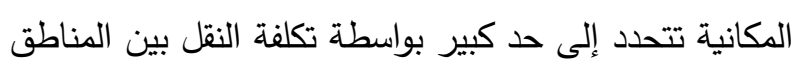
في حالة وجود منافسة حرة ولذا قد يختلف السعر المزرعي بين المناطق اعتماداً على قرب المنطقة من السوق، واستتاداً إلى ما سبق تتضح أهمية النقل كوظيفة تسويقية في ربط مناطق الإنتاج بمناطق الاستهلاك مع الأخذ في الاعتبار أنه

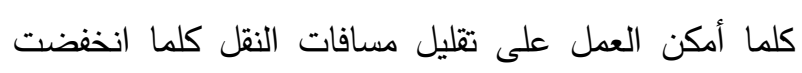
تكاليفه، لاسيما وأن تكاليف نقل محاصيل الخضر والفاكهة من مناطق الإنتاج إلى مناطق الاستهلاك تمثل الجانب الأكبر من التكاليف التسويقية.

وتثير استراتيجية التتمية الزراعية المستدامة لمصر حتى عام 2030(6) إلى أن الفاقد التسويقي من سلع الغذاء يرتفع إلى نسب قدرت متوسطاتها بنحو 30\% بالنسبة لمحاصيل الخضر والفاكهة، لذلك فقد عنيت استراتيجية التنمية الزراعية بالارتقاء بكفاءة عمليات التسويق بهدف الحد من هذا الفاقد بالقدر الذي ينعكس بصورة إيجابية على بلى أوضاع كل من المزارعين والمستهلكين، وبصفة عامة تستهدف استراتيجية التتمية الزراعية خفض معدلات الفاقد

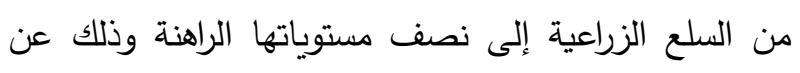
طريق تطوير منظومة التسويق الزراعي وسياساته من خلال وضع البرامج التسويقية التي من ضمنها تقليل مسافات النقل 
ولتحقيق هذا الهذف الرئيسي الذي يمكن من خلاله

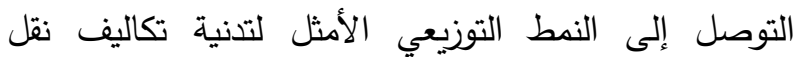
محاصيل الدراسة فقد استهدف البحث عدة أهداف فرعية تمثلت في تقدير الطاقات الإنتاجية لمحاصيل الدراسة على الدى مستوى مختلف الدحافظات وتحديد الفائض الإنتاجي الزائد

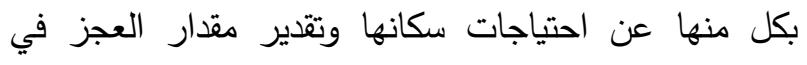
الاحتياجات الاستهلاكية لباقي الححافظات والتعرف على لئي

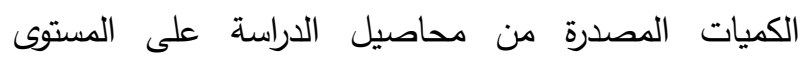

$$
\text { القومي. }
$$

$$
\text { الأسلوب البحثي ومصادر البيانات: }
$$

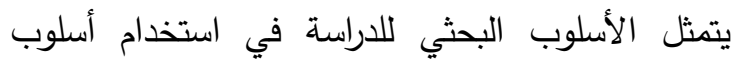

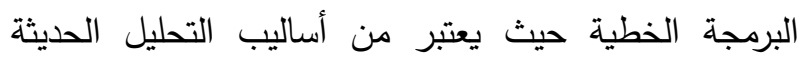

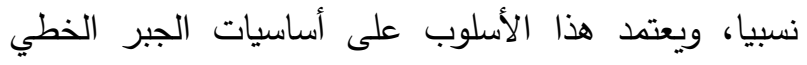

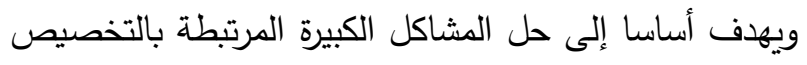
الأمثل للموارد على الرغم من محدوديتها، وتوجد مجالات عديدة لتطبيق هذا الأسلوب في مجال الإنتاج والتي من من ضمنها (نموذج النقل) وذلك يهذف إلى تدنية مسافات النقل لكل من البصل والبرتقال من المحافظات التي تمتلك فائضاً إلى المحافظات التي تتسم بوجود عجز من هذه الزروع، وتقوم فكرة نماذج النقل على أساس النقل الاقتصادي للوحدات

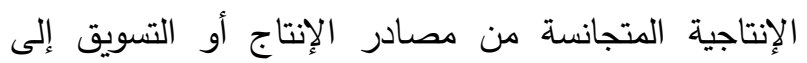

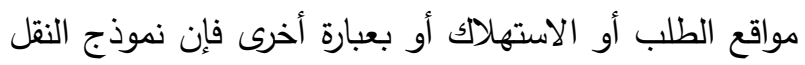

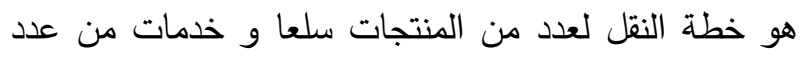

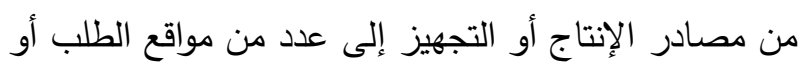

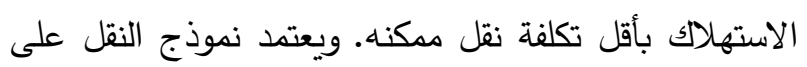

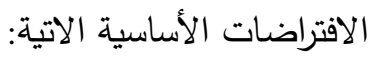
1- أن جميع المواد المنقولة بين المصادر ومناطق الطلب متجانسة (Homogeneous). 2- عدم وجود عوائق للنقل بين أي مصدر للتجهيز وأي

$$
\text { موقع للطلب. }
$$

5.6\%، 5.4\% لكل منها على الترتيب بإجمالي أهمية نسبية بلغت نحو 81.2\% من إجمالي إنتاج الجمهورية(8). واستتاداً إلى ما سبق تتضح أهمية دراسة التوزيع الأمثل

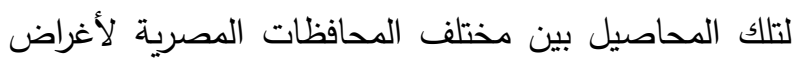
الاستهلاك المحلي وبين مختلف الموانئ المصرية لأغراض التصدير - التصنا

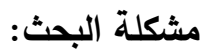

تتمثل مشكلة البحث في تمركز إنتاج محصولي البرتقال والبصل في عدد محدود من المحافظات في ظل عشوائية توجيهها لمختلف الأسواق أو مناطق استهلاكها وموانئ تصديرها الأمر الذي يترتب عليه ارتفاع تكاليف نقلها خلال

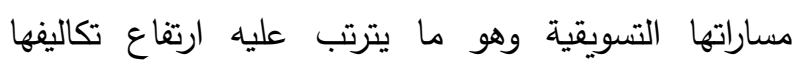

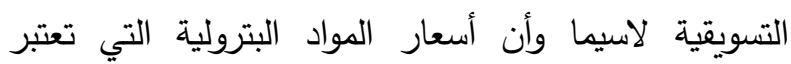
المحدد الرئيسي لتكلفة النقل قد شهدت في السنوات الأخيرة ارتفاعاً كبيراً. هذا بالإضافة إلى ما يترتب على عشوائية فئية

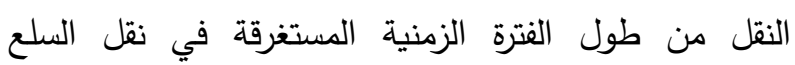
الزراعية موضع الدراسة مما يطيل من فترة تعرضها للعوامل الجوية وتغير خصائصها وإرتفاع نسبة الفاقد منها (2،3ن. ومن جانب آخر فإنه يترتب على عشوائية النقل زيادة

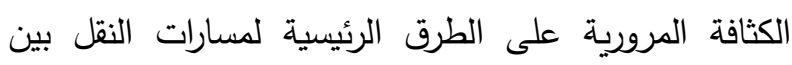

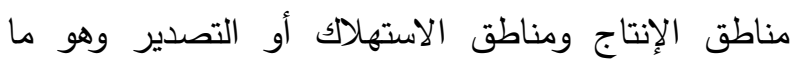
يترتب عليه زيادة التلوث البيئي نتيجة عوادم السيارات وفي الاستيات ذات الوقت زيادة الضغط على البنية الأساسية من الطرق.

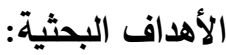

استهدف البحث بصفة رئيسية تدنية تكاليف النقل لدحصولي البرتقال والبصل من خلال تقليل مسافات النقل فيما بين مناطق الإنتاج ومناطق الاستهلاك أو التصدير حتى يمكن تقليل تكاليفها التسويقية بغية زيادة أسعارها المزرعية وتقليل أسعار المستهلكين لها بالإضافة إلى تقليل

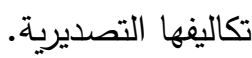


971 فيروز أحمد عبد المالك أحمد وسحر سعيد يعقوب محمد: التوزيع الأمثل لإنتاج محصولي البرتقال والبصل ............

4- نفترض أن الكمية المنقولة هي Xij من المصدر i إلى

$$
\text { المنطقة ز.j. }
$$

5- يتم تحويل مشكلة النقل (تدنية تكاليف النقل) إلى نموذج برمجة خطية هي بالأساس تتم بتحويل مشكلة النقل

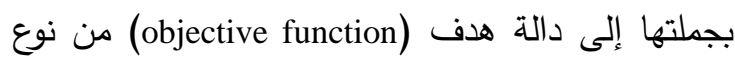
التدنية minimization وقيود constraints بحيث يكون من فئ النموذج الرياضي العام لتحويل مشكلة النقل إلى مشكلة

$$
\text { برمجة خطية كالتالي(4،3): }
$$

Min: $\mathbf{Z}=\sum_{1=0}^{\mathrm{m}} \quad \sum_{\mathrm{j}=1}^{\mathrm{n}} \mathbf{C}_{\mathbf{1 j} \mathrm{X}} \mathrm{X}_{\mathrm{ij}}$

\section{Subject to:}

$$
\begin{aligned}
& \sum_{\mathrm{i}=1}^{\mathrm{n}} \mathrm{Xij}_{\mathrm{ij}}=\mathbf{a i}=\mathbf{1}, \mathbf{2}, \mathbf{3}, \ldots \ldots . . ., \mathrm{n} \quad \text { قيود التجهيز } \\
& \sum_{\mathrm{j}=1}^{\mathrm{m}} \mathrm{X}_{\mathrm{ij}}=\mathbf{b j} \\
& \mathbf{j}=\mathbf{1}, \mathbf{2}, \mathbf{3}, \ldots \ldots . ., \mathrm{m} \\
& \sum_{\mathrm{i}=1}^{\mathrm{m}} \text { ai }=\sum_{\mathrm{j}=1}^{\mathrm{m}} \text { bi } \\
& \mathrm{X} \geq \mathbf{0} \text { for all (i,j) }
\end{aligned}
$$

ويوضح المحدد الأول أن الكميات المنقولة من محافظة الفائض (i) إلي جميع محافظات العجز (j) يجب أن يساوي فائض هذه المحافظة (ai)، وأيضاً المحدد الثاني يعني أن الن مجموع الكميات المنقولة إلي محافظة العجز (j) من جميع محافظات الفائض (i) يجب أن يساوي عجز (طلب) هذه المحافظة (bi)، أما المحدد الثالث فيعني أن إجمالي كميات الفائض ail

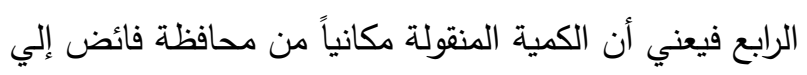
محافظة عجز لابد وأن يكون أكبر أو تساوي صفر . وقد اعتمدت الدراسة لتحقيق أهدافها علي العديد من النشرات التي يصدرها الجهاز المركزي للتعبئة العامة والإحصاء كنشرات الكتاب الاحصائي السنوي والنشرات والدراسات المختلفة المتعلقة بموضوع الدراسة والمواقع الخاصة بالمسافات بين مختلف المحافظات.
3- أن مجموع كمية الطلب المتوفرة لاى المصدر يساوي

$$
\text { مجموع كمية الطلب في المواقع. }
$$

4- أن تكاليف نقل المواد بين أي مصدر وأي موقع للطلب

$$
\text { معروفة ولن تتغير في الأمد القربب. }
$$

5- أن تكلفة النقل بين أي مصدر وأي موقع لا تتغير بتغير كمية المواد المنقولة.

ولتحديد محافظات العجز والفائض لمحصولي البصل والبرتقال فقد تم الاستتاد إلي المتوسط السنوي لإجمالي الإنتاج من كل محصول لكل محافظة خلال الفترة (20172019)، كما تم تقدير الكميات المستخدمة (المستهلكة) من من من المحصولين بكل محافظة استناداً إلى متوسط استهلاك الفرد من كلا المحصولين بناء على عدد السكان بكل محافظة وذلك في الفترة موضع الدراسة، والفرق بين الإنتاج والاستهلاك يمثل الفائض أو العجز في كل محصول ولكل المحافظات.

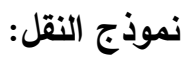

لتحديد التوزيع الأمثل للناتج المحلي من البرتقال والبصل والذي يحقق النهاية الدنيا لإجمالي مسافات التحويل المكاني بين المحافظات التي تمتلك فائض (i) أي محافظات العرض ومحافظات العجز (j) أي محافظات الطلب تم استخدام نموذج النقل الآتي:

1- نفترض ان عدد المصادر هو m وأن عدد مناطق الطلب

$$
\text { هي }
$$

2- نفترض أن تكلفة نقل الوحدة الواحدة من المواد المنقولة

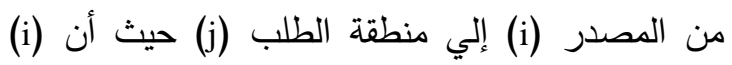
عبارة عن رقم 1 إلي m و (j) عبارة عن رقم 1 إلى

$$
\text { وأن هذه التكلفة هي Cij. }
$$

3- أن كل مصدر يحتوي علي كمية من البضاعة تصل إلى حد معين ولنفترض أن المصدر (i) يحتوي ai وأن

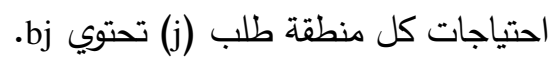


فدان بمعل نمو بلغ نحو 34\% سنويا، كما أخذ أيضا الإنتاج المحلي والصادرات من البرتقال اتجاها تزايديا معنوي إحصائيا خلال فترة الدراسة مقداره حوالي 0.038، 34.099 ألف طن بمعدل نمو بلغ نحو 3.8\%، 3.7\% سنويا لكل

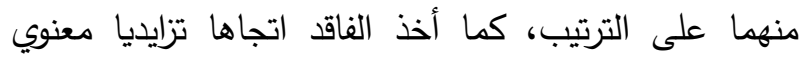

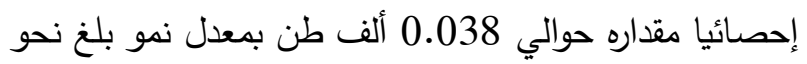
3.8\% سنوياً، بينما أخذ نصيب الفرد من البرتقال خلال فترة الدراسة اتجاها تناقصياً معنوي إحصائيا خلال فترة الدراسة الدنال

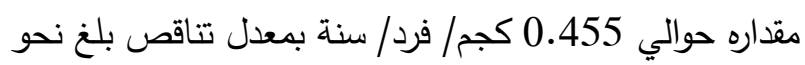

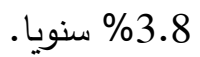

ومن خلال دراسة الإتتاج الحالي لمحصول البرتقال كمتوسط للفترة (2017-2019) على مستوى محافظات الجمهورية يتبين من جدول (3) أنه موزع على مناطق الجمهورية الأربعة وهي الوجه البحري ومصر الوسطى الجهى

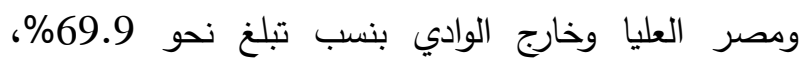
2.5\%، 3.1\%، 24.5\% لكل منهما على الترتيب من متوسط الإنتاج والذي يبلغ حوالي 3100.1 ألف طن خلال فترة الدراسة، ووجد أن كل من محافظات البحيرة، الإسماعيلية، القليوبية، الثرقية، المنوفية، ومنطقة النوبارية

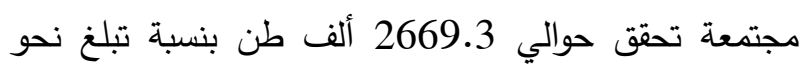
86.1 من إجمالي الجمهورية، يليهم محافظات الغربية،

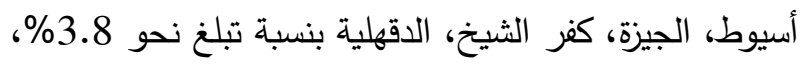
2.7\%، 1.4\%، 1.1\%، 1.1\% من إجمالي إنتاج الجمهورية وبالتالي فنبين أن إنتاج المحافظات السابقة الذكر يبلغ حوالي 2981.5 ألف طن بنسبة تبلغ نحو الجناج إجمالي إنتاج الجمهورية في حين تمثل باقي المحافظات نحو 3.8 من إجمالي إنتاج الجمهورية.

\section{النتائج ومناقشتها}

الوضع الراهن لإتتاج واستهلاك محصول البرتقال بمحافظات الجمهورية

يعتبر الإنتاج المحلي من البرتقال هو المصدر الرئيسي

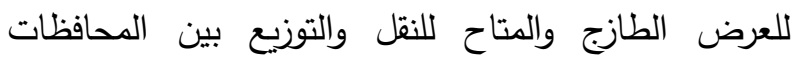
المحققة للفائض والمحافظات المحققة للعجز لسد الاحتياجات اللازمة لاستهلاكها من البرتقال وبدراسة تطور المساحة المزروعة من البرتقال خلال الفترة (2005-2019) يتضح من جدول (1) أن إجمالي الدساحة المزروعة بالبرتقال على المعال

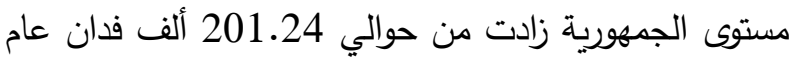
2005 إلى حوالي 316.76 ألف فدان عام 2019 بنسبة زيادة بلغت نحو 57.4\% مما أدى إلى زيادة إنتاج البرتقال من حوالي 1940.4 ألف طن عام 2005 إلى حوالي 3066.7 ألف طن عام 2019 بنسبة زيادة بلغت نحو 58.04 الال فترة الدراسة .

كما ازدادت كمية الصادرات خلال فترة الدراسة من حوالي 214.2 ألف طن عام 2005 إلى حوالي 1953 ألف طن عام 2019 بنسبة زيادة قدرها نحو 811.8\%، بينما تذبذبت كمية الفاقد بين الزيادة والنقصان حيث بلغت أدناها عام 2005 بحوالي207 ألف طن وبلغت أقصاها عام 2014 بحوالي 502 ألف طن وأيضا تذبذب نصيب الفرد من البرتقال بين الزيادة والنقصان حيث بلغ أدناه بحوالي 6.3

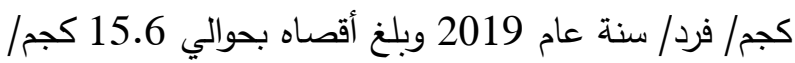

$$
\text { فرد/ سنة في عام } 2006 \text { ـ مندة عام }
$$

يتضح من معادلات الاتجاه الزمني بجدول (2) أن المساحة المزروعة من البرتقال قد أخذت اتجاها تزايديا معنوي إحصائيا خلال فترة الدراسة مقداره حوالي 0.34 ألف الف الفاليا 
973 فيروز أحمد عبد المالك أحمد وسحر سعيد يعقوب محمد: التوزيع الأمثل لإنتاج محصولي البرتقال والبصل .......

جدول 1. تطور المساحة والإنتاج والإنتاجية والصادرات والفاقد ونصيب الفرد من محصول البرتقال في جمهورية مصر العربية خلال الفترة (2005 - 2019 )

\begin{tabular}{|c|c|c|c|c|c|c|}
\hline (كجم/ فرد/سنة) الفرد) & 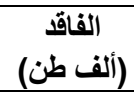 & (الصفادرات) & الإتتاجية & (ألف طن) & (ألف فداحة) & البيان \\
\hline 15 & 207 & 214.2 & 9.6 & 1940.4 & 201.24 & 2005 \\
\hline 15.6 & 276 & 282.7 & 10.1 & 2120 & 209.12 & 2006 \\
\hline 14.8 & 267 & 271.6 & 9.7 & 2054.6 & 212.71 & 2007 \\
\hline 12 & 222 & 454.4 & 9.6 & 2138.4 & 222.24 & 2008 \\
\hline 12 & 225 & 821.8 & 10.1 & 2372.3 & 234.57 & 2009 \\
\hline 12.3 & 237 & 636.3 & 10 & 2401 & 241.1 & 2010 \\
\hline 11.7 & 230 & 1042.3 & 9.8 & 2577.7 & 262.91 & 2011 \\
\hline 12 & 398 & 607.7 & 9.9 & 2786.4 & 282.69 & 2012 \\
\hline 11.5 & 391 & 1108.9 & 9.5 & 2855.02 & 299.04 & 2013 \\
\hline 14.4 & 502 & 877.3 & 10.4 & 3135.9 & 300.95 & 2014 \\
\hline 13.3 & 475 & 1353 & 10.7 & 3351.4 & 312.58 & 2015 \\
\hline 9.8 & 360 & 1339 & 10.6 & 2939.1 & 277 & 2016 \\
\hline 10.3 & 397 & 1369 & 10.3 & 3147.5 & 306.86 & 2017 \\
\hline 8.4 & 330 & 1619 & 10.4 & 3086 & 296.49 & 2018 \\
\hline 6.3 & 251 & 1953 & 10.5 & 3066.7 & 316.76 & 2019 \\
\hline \multirow[t]{5}{*}{11.96} & 317.87 & 930.01 & 10.08 & 2664.8 & 265.1 & المتوسط \\
\hline & \multirow{3}{*}{\multicolumn{6}{|c|}{ - الجهاز المركزي للتعبئة العامة والإحصاء، النشرة السنوية لحركة الإنتاج والتجارة الخارجية والمتاح للاستهلاك من }} \\
\hline & & & & & & \\
\hline & & & & & & \\
\hline & & بداد مختلفة & St & ع ع الثئون & تصلاح ا' & - وزارن \\
\hline
\end{tabular}

جدول2. معالم ومؤشرات الاتجاه الزمني للمساحة المثمرة والإنتاج والإنتاجية والصادرات والفاقد ونصيب الفرد من محصول البرتقال في جمهورية مصر العزبية خلال الفترة (2005 - 2019 )

\begin{tabular}{|c|c|c|c|c|c|c|}
\hline $\begin{array}{c}\text { معدل النمو } \\
\text { \% }\end{array}$ & $\mathbf{F}$ & $\mathbf{R}^{2}$ & $\mathbf{T}$ & 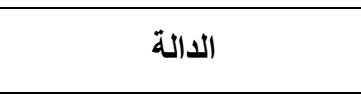 & المتوسط & المتغير \\
\hline 34 & $88.689^{* *}$ & 0.872 & $9.418^{* *}$ & $\mathrm{Y}=\mathrm{e}^{5.299+0.34 \mathrm{X}}$ & 265.1 & المساحة \\
\hline 3.8 & $86.966^{* *}$ & 0.87 & $9.326^{* *}$ & $Y=e^{7.575+0.038 x}$ & 2664.8 & الإنتاج \\
\hline 0.6 & $13.020^{* *}$ & 0.50 & $3.608^{* *}$ & $\mathrm{Y}=\mathrm{e}^{2.261+0.006 \mathrm{X}}$ & 10.08 & الإنتاجيَة \\
\hline 3.7 & $117.409^{* *}$ & 0.90 & $10.836^{* *}$ & $Y=111.989+34.099 X$ & 930.01 & الصَّادر اتث \\
\hline 3.8 & $6.294^{*}$ & 0.326 & $2.509^{*}$ & $\mathrm{Y}=\mathrm{e}^{5.417+0.038 \mathrm{X}}$ & 317.87 & الفاقد \\
\hline-3.8 & $23.026^{* *}$ & 0.639 & $-4.799^{* *}$ & $Y=15.603-0.455 X$ & 11.96 & نصيب الفرد \\
\hline
\end{tabular}

المصدر : جمعت وحسبت من التحليل الإحصائي للبيانات الواردة بجدول (1).

العرض الطازج من الإنتاج المحلي والطلب الاستهلاكي المقدر لكل محافظة خلال فترة الدراسة. وهذا الفرق إذا كان موجب إب يعبر عن فائض بهذه المحافظة وهو المتاح لنقلة إلى المحافظات التي بها عجز ( ذات الفرق السالب ) خلال نفس الفترة.
تقدير الفائض والعجز من محصول البرتقال بمحافظات الجمهوربية

يعرف الفائض أو العجز من المحصول بمحافظات الجمهورية بأنه الفرق بين الناتج المحلي والطلب الاستهلاكي لكل محافظة خلال فترة زمنية معينة أي يتمثل في الفرق بين 
ويتبين من جدول (3) أن إجمالي الفائض لمحصول تمثل نحو 69.9\% من إجمالي الفائض موزعة على محافظات البرتقال على مستوى الجمهورية كمتوسط للفترة (2017- البحيرة، الغربية، كفر الثيخ، الثرقية، الإسماعيلية، السويس، 2019) يبلغ حوالي 2627.7 ألف طن حيث حققت منطقة المنوفية، القليوبية بنسب بلغت نحو 23.4\%، 2.9\%

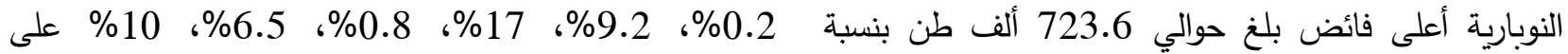
تمثل نحو 27.5\% من إجمالي الفائض، كما بلغ الفائض الترتيب في حين تمثل محافظات خارج الوادي ومصر العليا لمحافظات الوجه البحري حوالي 1835.8 ألف طن بنسبة نحو 28.4\%، 1.7 من متوسط الفائض من البرتقال

جدول 3. الأهمية النسبية للإنتاج والاستهلاك والفائض والعجز من محصول البرتقال خلال الفترة (2017-2019)

\begin{tabular}{|c|c|c|c|c|c|c|c|c|}
\hline \multicolumn{2}{|c|}{ العجز } & \multicolumn{2}{|c|}{ الفائض } & \multicolumn{2}{|c|}{ الاستهلاك " } & \multicolumn{2}{|c|}{ الإنتاج } & \multirow[b]{2}{*}{ المحافظة } \\
\hline$\%$ & 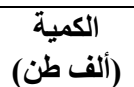 & $\%$ & 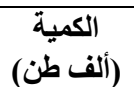 & $\%$ & 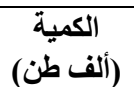 & $\%$ & (ألف طنية & \\
\hline 10.7 & 36.6 & - & - & 5.4 & 44.1 & 0.2 & 7.6 & الإسكندرية \\
\hline - & - & 23.4 & 613.6 & 6.6 & 53.2 & 21.5 & 666.8 & البحيرة \\
\hline - & - & 2.9 & 75.5 & 5.3 & 42.9 & 3.8 & 118.4 & الغربية \\
\hline - & - & 0.2 & 5 & 3.6 & 28.9 & 1.1 & 33.9 & كفر الثيخ \\
\hline 6.6 & 22.4 & - & - & 6.9 & 55.6 & 1.1 & 33.2 & الدقهلية \\
\hline 3.7 & 12.6 & - & - & 1.6 & 12.8 & 0.01 & 0.2 & دمياط \\
\hline - & - & 9.2 & 241.9 & 7.6 & 61.6 & 9.8 & 303.5 & الثرقية \\
\hline - & - & 17.0 & 445.5 & 1.4 & 11.2 & 14.7 & 456.7 & الإسماعيلية \\
\hline 1.8 & 6.2 & - & - & 0.8 & 6.4 & 0.01 & 0.2 & بور سعيد \\
\hline - & - & 0.8 & 21.5 & 0.8 & 6.2 & 0.9 & 27.7 & السويس \\
\hline - & - & 6.5 & 170.2 & 4.6 & 36.9 & 6.7 & 207.2 & المنوفية \\
\hline - & - & 10.0 & 262.6 & 5.9 & 48.2 & 10.0 & 310.8 & القليو بية \\
\hline 23.4 & 79.7 & - & - & 10.1 & 81.6 & 0.1 & 1.8 & القاهرة \\
\hline 46.3 & 157.48 & 69.9 & 1835.8 & 60.4 & 489.7 & 69.9 & 2167.4 & الوجه البحري \\
\hline 8.8 & 30 & - & - & 9.1 & 74.1 & 1.4 & 44.1 & الجيزة \\
\hline 1.8 & 6.1 & - & - & 3.4 & 27.3 & 0.7 & 21.1 & بني سويف \\
\hline 7.7 & 26 & - & - & 3.8 & 31.1 & 0.2 & 5.1 & الفيوم \\
\hline 11.8 & 40.3 & - & - & 5.9 & 47.6 & 0.2 & 7.3 & المنيا \\
\hline 30.1 & 102.5 & - & - & 22.2 & 180.1 & 2.5 & 77.6 & مصر الوسطي \\
\hline- & - & 1.7 & 44.6 & 4.7 & 38 & 2.7 & 82.6 & أسيوط \\
\hline 10.1 & 34.3 & - & - & 5.3 & 43.1 & 0.3 & 8.8 & سو هاج \\
\hline 7.8 & 26.5 & - & - & 3.4 & 27.4 & 0.03 & 0.9 & قنا \\
\hline 2.8 & 9.5 & - & - & 1.3 & 10.8 & 0.04 & 1.3 & الأقصر \\
\hline 2.8 & 9.5 & - & - & 1.6 & 12.7 & 0.1 & 3.3 & أسوان \\
\hline 23.4 & 79.68 & 1.7 & 44.6 & 16.3 & 132 & 3.1 & 96.9 & مصر العليا \\
\hline- & - & 0.8 & 20.3 & 0.3 & 2.1 & 0.7 & 22.3 & الو ادي الجديد \\
\hline - & - & 0.1 & 3.3 & 0.5 & 3.8 & 0.2 & 7.1 & مطروح \\
\hline - & - & 0.003 & 0.1 & 0.5 & 3.9 & 0.1 & 3.9 & شمال سيناء \\
\hline 0.1 & 0.47 & - & - & 0.1 & 0.9 & 0.01 & 0.4 & جنوب سيناء \\
\hline- & - & 27.5 & 723.6 & 0.1 & 0.7 & 23.4 & 724.3 & النوبارية \\
\hline 0.1 & 0.47 & 28.4 & 747.3 & 1.4 & 11.3 & 24.5 & 758.1 & خارج الوادي \\
\hline 100 & 340.14 & 100.0 & 2627.7 & 100.0 & 810.6 & 100.0 & 3100.1 & إجمالي الجمهورية \\
\hline
\end{tabular}

* تم تقديره بتوزيع إجمالي إنتاج البرتقال للجمهورية على مستوى المحافظات وفقا للأهمية النسبية لعدد السكان لكل محافظة خلال الفترة (2017-2019) مرجح بواسطة

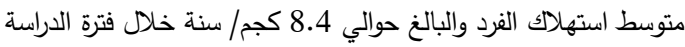

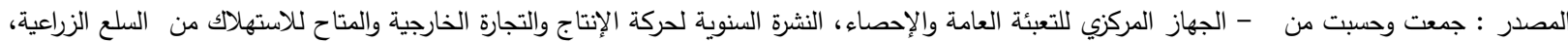
أعداد مختلفة- وزارة الزراعة واستصلاح الأراضي، قطاع الثئون الاقتصادية ، نشرة الإحصاءات الزراعية ، أعداد مختلفة 
975 فيروز أحمد عبد المالك أحمد وسحر سعيد يعقوب محمد: التوزيع الأمثل لإنتاج محصولي البرتقال والبصل .......

الإسكندرية، الدقهلية، دمياط، بور سعيد، القاهرة، الجيزة، بني

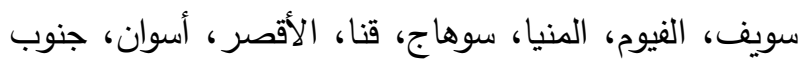
سيناء

ويتضح من جدول (5) أن نتائج نموذج النقل للبرتقال تشير إلى عدم توزيع الفائض من البرتقال لكل من محافظات

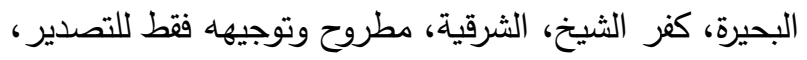
بينما يتم توزيع فائض محافظة الغربية والبالغ حوالي 75.5 ألف طن إلى محافظات الدقهلية، دمياط بكميات تبلغ حوالي 22.4، 12.6ألف طن على الترتيب تمثل نحو 29.7\%، 16.7\% من جملة الفائض لمحافظة الغربية على الترتيب ويتبقى لديها فائض تصدير يقدر بحوالي 40.5 ألف طن يمثل نحو 53.6\% من جملة الفائض لمحافظة الغربية. بينما يتم توزيع الفائض لمحافظة الإسماعيلية والبالغ حوالي 454.5 ألف طن إلى محافظة بورسعيد بكمية تبلغ حوالي 6.2 ألف طن بنسبة تمثل نحو 1.4\% من جملة الفائض لمحافظة الإسماعيلية ويتبقى لديها فائض تصدير يقدر بحوالي 448.3 ألف طن يمثل نحو 98.6\% من جملة الفائض لمحافظة الإسماعيلية. كما يتم توزيع الفائض لمحافظة السويس والبالغ حوالي 21.5 ألف طن إلى محافظة جنوب سيناء بكمية تبلغ حوالي 0.4 ألف طن بنسبة تمثل نحو 1.9\% من جملة الفائض لمحافظة السويس ويتبقى لديها فائض تصدير يقدر بحوالي 21.1 ألف طن يمثل نحو 98.1 من جملة الفائض لمحافظة السوي. وأيضا يتم توزيع الفائض لمحافظة المنوفية والبالغ حوالي 170.2 ألف طن إلى محافظة قنا بكمية تبلغ حوالي 14.9 ألف طن بنسبة تمثل نحو 8.8\% من جملة الفائض لمحافظة المنوفية ويتبقى لديها فائض تصدير يقدر بحوالي 155.3 ألف طن يمثل نحو 91.2\% من جملة الفائض لمحافظة المنوفية. كما يتم توزيع فائض محافظة القليوبية والبالغ حوالي 262.6 ألف طن إلى محافظات القاهرة، الجيزة، بني سويف، الفيوم، المنيا بكميات تبلغ حوالي 79.7، 30، 6.1، 26، 40.3 ألف طن
خلال فترة الدراسة بينما لا يوجد فائض في محافظات مصر

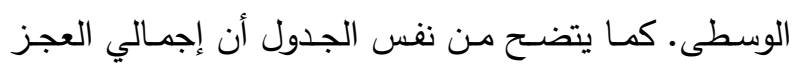
الحالي في بعض المحافظات في متوسط الفترة (20172019) يبلـن حوالي 340.14 ألف طن حيث يبلـغ العجز أقصــاه بمحافظـات القـاهرة، المنيـا، الإسـكندريـة، سـوهاج، الجيزة، الفيوم، قنا بكميات عجز تبلغ حوالي 79.9، 40.3، 36.6، 34.3، 30، 26.5، 26 ألـفـ طـن بنسـب تمثـل

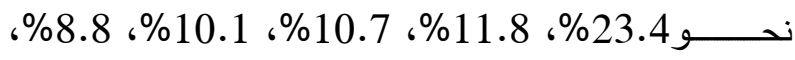
\%.8\% 7.7 مـن إجمـالي العجز لمحافظـات الجمهوريـة يلـيهم محافظـات الدقهليـة، دميـاط، الأقصـر ، أسـوان، بـور سعيد، بني سويف، جنوب سيناء بكميات عجز تبلغ حوالي 22.4، 12.6، 9.5، 9.5، 6.5، 6.1،

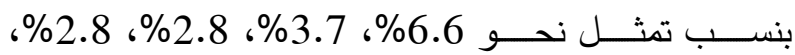
1.8\%، 1.8\%، 0.1\% من إجمالي العجز على الترتيب. نتائج نموذج النقل الأمثل لمحصول البرتقال بين محافظات الجمهورية

باستعراض خطة النقل المثلى لمحصول البرتقال بين محافظات الفائض ومحافظات العجز باستخدام النموذج الاقتصادي الرياضي للنقل الوارد بجدول (4) بهدف تدنية إجمالي مسافة النقل (كم/ طن) باعتبارها من أهم العوامل المحددة لتكلفة وزمن نقل الفائض من محصول البرتقال من من ناحية ووصول هذا الفائض الطازج بحالة جيدة وفي الوقت المناسب للمستهلك من ناحية أخرى مما يساعد على تحقيق السعر المناسب لكل من المنتج والمستهلك.

ويوضح جدول (5) نتائج التوزيع الأمثل للفائض من البرتقال والذي يحقق النهاية الدنيا لإجمالي مسافة نقل البرتقال من محافظات الفائض والبالغ عددها 13 محافظة وهي البحيرة، الغربية، كفر الثيح، الثرقية، الإسماعيلية، السويس، المنوفية، القليوبية، أسيوط، الوادي الجديد، مطروح، شمال سيناء، منطقة النوبارية إلى محافظات العجز وهي 
جدول4. مصفوفة النقل لمحصول البرتقال بين مناطق العرض والطلب خلال متوسط الفترة ( 2017 - 2019 )

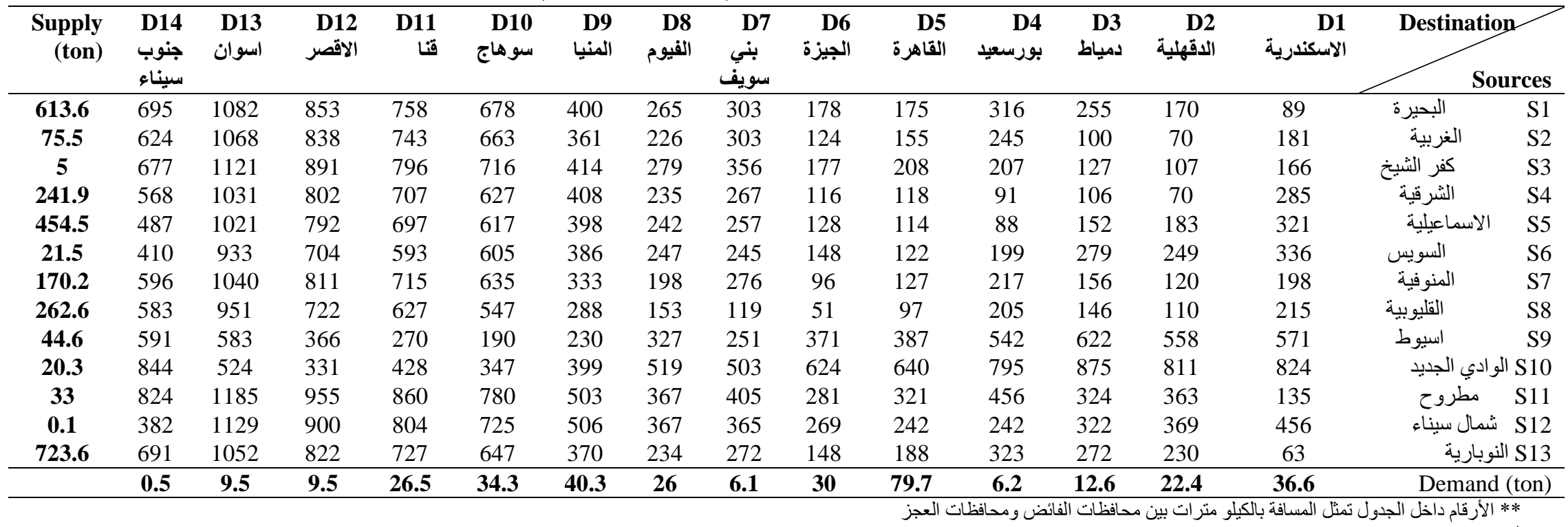


جدول 5. التوزيع الأمثل لفائض الإنتاج من البرتقال بالطن بين مناطق الجمهورية كمتوسط الفترة ( 2017 - 2019 )

\begin{tabular}{|c|c|c|c|c|c|c|c|c|c|c|c|c|c|c|c|c|c|}
\hline للتصدير & $\begin{array}{c}\text { Supply } \\
\text { (ton) }\end{array}$ & سنوب & اسوان & $\begin{array}{l}\text { D12 } \\
\text { الاقص }\end{array}$ & $\begin{array}{c}\text { D11 } \\
\text { قu }\end{array}$ & $\begin{array}{c}\text { D10 } \\
\text { سوهاج }\end{array}$ & $\begin{array}{c}\text { D9 } \\
\text { المنيا }\end{array}$ & $\begin{array}{c}\text { D8 } \\
\text { الفيوم }\end{array}$ & سويفي & $\begin{array}{c}\text { D6 } \\
\text { الجيزة }\end{array}$ & $\begin{array}{c}\text { D5 } \\
\text { القاهرة }\end{array}$ & $\begin{array}{c}\text { D4 } \\
\text { بورسعيد }\end{array}$ & $\begin{array}{c}\text { D3 } \\
\text { دمياط }\end{array}$ & الدقهلية & $\begin{array}{c}\text { D1 } \\
\text { الاسكندرية }\end{array}$ & \multicolumn{2}{|c|}{ Destination } \\
\hline 613.6 & 613.6 & & & & & & & & & & & & & & & البحيرة & S1 \\
\hline 40.5 & 75.5 & & & & & & & & & & & & 12.6 & 22.4 & & الغربية & $\mathrm{S} 2$ \\
\hline 5 & 5 & & & & & & & & & & & & & & & كفر الثيخ & S3 \\
\hline 241.9 & 241.9 & & & & & & & & & & & & & & & الثرقية & S4 \\
\hline 448.3 & 454.5 & & & & & & & & & & & 6.2 & & & & الاسماعيلية & S5 \\
\hline 21.1 & 21.5 & 0.4 & & & & & & & & & & & & & & السويس & S6 \\
\hline 155.3 & 170.2 & & & & 14.9 & & & & & & & & & & & المنوفية & S7 \\
\hline \multirow[t]{3}{*}{80.5} & 262.6 & & & & & & 40.3 & 26 & 6.1 & 30 & 79.7 & & & & & القليو بية & S8 \\
\hline & 44.6 & & & & 11.6 & 33 & & & & & & & & & & اسيوط & S9 \\
\hline & 20.3 & & 9.5 & 9.5 & & 1.3 & & & & & & & & & & \multicolumn{2}{|c|}{ S10 الو ادي الجديد } \\
\hline \multirow[t]{2}{*}{33} & 33 & & & & & & & & & & & & & & & مطروح & S11 \\
\hline & 0.1 & 0.1 & & & & & & & & & & & & & & شمال سيناء & $\mathrm{S} 12$ \\
\hline \multirow[t]{2}{*}{687} & 723.6 & & & & & & & & & & & & & & 36.6 & النوبارية & S13 \\
\hline & & 0.5 & 9.5 & 9.5 & 26.5 & 34.3 & 40.3 & 26 & 6.1 & 30 & 79.7 & 6.2 & 12.6 & 22.4 & 36.6 & \multicolumn{2}{|c|}{ Demand (ton) } \\
\hline
\end{tabular}

المصدر: نتائج حل النموذج القياسي للنقل بجدول (4) باستخدام برنامج النقل Transportation Model باستخدام برنامج 
يعتبر الإنتاج المحلي من البصل هو المصدر الرئيسي

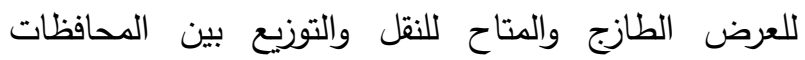
المحققة للفائض والمحافظات المحققة للعجز لسد الاحتياجات اللازمة لاستهلاكها من البصل وبدراسة تطور المساحة المزروعة من البصل خلال الفترة (2005-2019) يتضح من جدول (6) أن إجمالي المساحة المزروعة بالبصل على لئل مستوى الجمهورية زادت من حوالي 101.39 ألف فدان عام الجماني 2005 إلى حوالي 190.63 ألف فدان عام 2019 بنسبة زيادة بلغت نحو 88.02\% مما أدى إلى زيادة إنتاج البصل من حوالي 1302.13 ألف طن عام 2005 إلى حوالي 2857.34 ألف طن عام 2019 بنسبة زيادة بلغت نحو

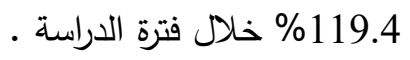

كما ازدادت كمية الصادرات خلال فترة الدراسة من

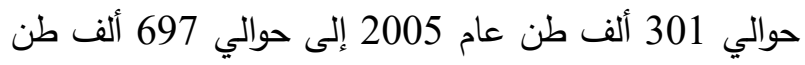
عام 2019 بنسبة زيادة قدرها نحو 131.6\%، بينما تذبذبت

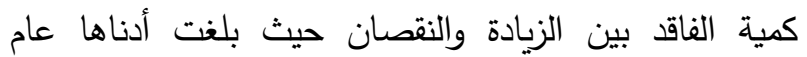
2007 بحوالي 68 ألف طن وبلغت أقصاها عام 2015 بحوالي 509 ألف طن وأيضاً تذبذب نصيب الفرد من البصل

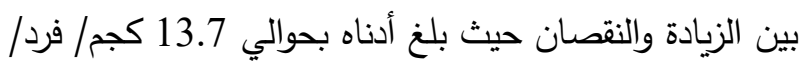

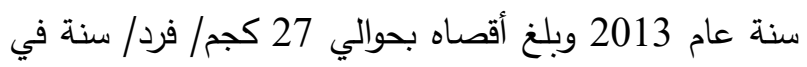

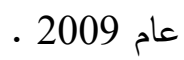

يتضح من معادلات الاتجاه الزمني بجدول (7) أن المساحة المزروعة من البصل قد أخذت اتجاها تزايديا معنوي إحصائيا خلال فترة الدراسة مقداره حوالي 0.078 ألف فدان الندان الندان بمعدل نمو بلغ نحو 7.8\% سنويا، كما أخذ أيضا الإنتاج المحلي والصادرات من البصل اتجاها تزايديا معنوي إحصائيا

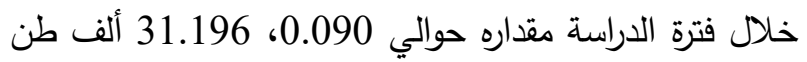

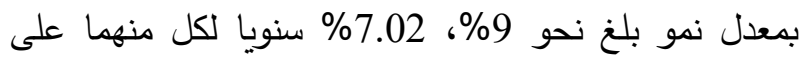
الترتيب، كما أخذ الفاقد اتجاها تزايديا معنوي إحصائيا مقداره

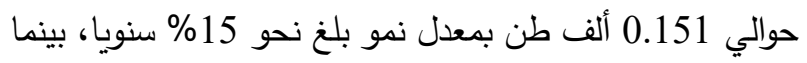
أخذ نصيب الفرد من البصل خلال فترة الدراسة اتجاها تناقصياً غير معنوي إحصائيا خلال فترة الدراسة.
على الترتيب تمثل نحو 30.4\%، 11.4\%، 2.3\%؛ 9.9\%، 15.3\% من جملة الفائض لمحافظة القليوبية على الترتيب ويتبقى لديها فائض تصدير يقدر بحوالي 80.5 ألف طن يمثل نحو 30.7\% من جملة الفائض لمحافظة القليوبية. كما يتم توزيع الفائض لهحافظة أسيوط والبالغ حوالي 44.6 ألف طن إلى محافظات سوهاج، قنا بكميات تبلغ حوالي 33، 11.6 ألف طن على الترتيب بنسبة تمثل نحو 74\%، 26\% لكل منهما على الترتيب من جملة الفائض لمحافظة أسيوط، بينما يتم توزيع فائض محافظة الوادي الجديد والبالغ حوالي 20.3 ألف طن إلى محافظات سوهاج، الأقصر، أسوان بكميات تبلغ حوالي 1.3، 9.5، 9.5 ألف طن على الترتيب تمثل نحو 6.4\%، 46.4\% 46.8 من جملة الفائض لمحافظة الوادي الجديد على الترتيب. وأيضا يتم توزيع الفائض لمحافظة شمال سيناء والبالغ حوالي 0.1 ألف طن إلى محافظة جنوب سيناء بكمية تبلغ حوالي 0.1 ألف طن بنسبة تمثل نحو 100\% من إلى

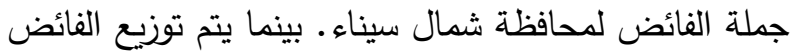

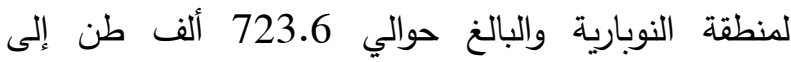

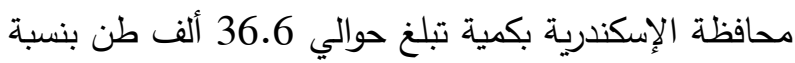
تمثل نحو 5.1\% من جملة الفائض لمنطقة النوبارية ويتبقى لديها فائض تصدير يقدر بحوالي 687 ألف طن يمثل نحو 94.9 من جملة الفائض لكنطقة النوبارية.

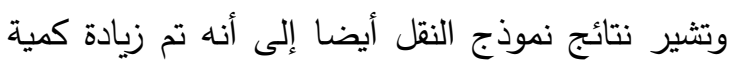
الصادرات من البرتقال من 1647 ألف طن إلى حوالى الثي ندالي 2.33 مليون طن أي بزيادة قدرها 683 ألف طن تمثل نحو 41.5 من متوسط كمية الصادرات من البرتقال خلال فترة الدراسة وبالتالي فإن إعادة توزيع البرتقال بين مناطق ومحافظات الجمهورية يؤدي إلى تقليل الفاقد وكذلك زيادة الصادرات وتقليل العز في ميزان الددفوعات. الوضع الراهن لإنتاج واستهلاك محصول البصل بمحافظات

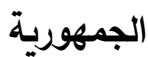


979 فيروز أحمد عبد المالك أحمد وسحر سعيد يعقوب محمد: التوزيع الأمثل لإنتاج محصولي البرتقال والبصل .......

منطقة النوبارية مجتمعة تحقق حوالي 1772.3 ألف طن بنسبة تبلغ نحو 63.6\% من إجمالي الجمهورية، يليهم محافظات

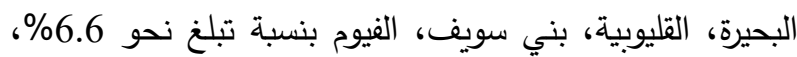
6.1\%، 5.6\%، 5.4\%، من إجمالي إنتاج الجمهورية وبالتالي فتبين أن إنتاج المحافظات السابقة الذكر يبلغ حوالي 2432.7 ألف طن بنسبة تبلغ نحو 87.3\% من إجمالي إنتاج الجمهورية في حين تمثل باقي المحافظات نحو 12.7\% من إجمالي إنتاج

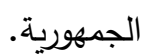

ومن خلال دراسة الإنتاج الحالي لمحصول البصل كمتوسط للفترة (2017-2019) على مستوى محافظات الجمهورية يتبين من جدول (8) أنه موزع على مناطق الجمهورية الأربعة وهي الوجه البحري ومصر الوسطى ومصر العليا وخارج الوادي بنسب تبلغ نحو 62.2\%، 14.7\% 13.7\%، 9.4\% لكل منهما على الترتيب من متوسط الإنتاج والذي يبلغ حوالي 2786.3 ألف طن خلال فترة الدراسة، ووجد أن كل من محافظات الغربية، الدقهلية، الثرقية، سوهاج،

جدول 6. تطور المساحة والإنتاج والإنتاجية والصادرات والفاقد ونصيب الفرد من محصول البصل في جمهورية مصر العربية

\begin{tabular}{|c|c|c|c|c|c|c|}
\hline (كجم/ فرد/سنة) & (ألف طاقن) & (ألف طنادر) & الإنتاجية & (ألف طتن) & (ألف فداحة) & البيان \\
\hline 21.8 & 82 & 301 & 12.84 & 1302.13 & 101.39 & 2005 \\
\hline 18.4 & 70 & 205 & 12.68 & 752.51 & 59.36 & 2006 \\
\hline 17.6 & 68 & 201 & 13.28 & 1067.33 & 80.37 & 2007 \\
\hline 21.3 & 84 & 261 & 13.67 & 1389.26 & 101.6 & 2008 \\
\hline 27 & 109 & 235 & 13.56 & 1563.36 & 115.3 & 2009 \\
\hline 18.7 & 284 & 512 & 14.19 & 2197.23 & 154.86 & 2010 \\
\hline 19.3 & 350 & 491 & 14.22 & 2157.32 & 151.72 & 2011 \\
\hline 16.2 & 364 & 566 & 14.26 & 2917.22 & 204.62 & 2012 \\
\hline 13.7 & 223 & 611 & 14.87 & 2021.42 & 135.96 & 2013 \\
\hline 19.9 & 470 & 367 & 14.96 & 2535.84 & 169.48 & 2014 \\
\hline 21 & 509 & 551 & 14.67 & 2888.79 & 196.97 & 2015 \\
\hline 16.3 & 404 & 441 & 14.21 & 4667.64 & 328.58 & 2016 \\
\hline 18.2 & 400 & 686 & 15.28 & 2815.16 & 184.24 & 2017 \\
\hline 18.2 & 407 & 545 & 14.71 & 2796.34 & 190.15 & 2018 \\
\hline 18.3 & 417 & 697 & 15 & 2857.34 & 190.63 & 2019 \\
\hline 19.06 & 282.73 & 444.67 & 14.16 & 2261.9 & 157.68 & المتوسط \\
\hline
\end{tabular}

المصدر: الجهاز المركزي للتعبئة العامة والإحصاء، النشرة السنوية لحركة الإنتاج والتجارة الخارجية والمتاح للاستهلاك من السلع الزراعية، أعداد متفرقة

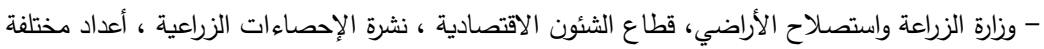

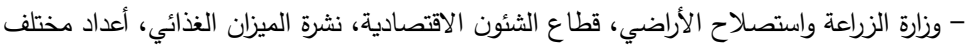

جدول 7. معالم ومؤشرات الاتجاه الزمني للمتغيرات الاقتصادية المرتبطة بالمساحة والإنتاج والإنتاجية والصادرات والفاقد ونصيب الفرد من محصول البصل في جمهورية مصر العربية خلال الفترة (2005 - 2019 )

\begin{tabular}{|c|c|c|c|c|c|c|}
\hline معدل التغير \% & $\mathbf{F}$ & $\mathbf{R}^{2}$ & $\begin{array}{l}\text { T لمعار } \\
\end{array}$ & الدالة & المتوسط & المتغير \\
\hline 7.8 & $26.044^{* *}$ & 0.667 & $5.099^{* *}$ & $Y=e^{4.352+0.078 X}$ & 157.68 & المساحة \\
\hline 9 & $33.205^{* *}$ & 0.719 & $5.762^{* *}$ & $Y=e^{6.909+0.090 X}$ & 2261.9 & الإنتاج \\
\hline 1.14 & $53.212^{* *}$ & 0.804 & $7.295^{* *}$ & $Y=12.875+0.161 X$ & 14.16 & الإنتاجية \\
\hline 7.02 & $25.116^{* *}$ & 0.659 & $5.012^{* *}$ & $Y=195.095+31.196 X$ & 444.67 & الصنادرات \\
\hline 15 & $40.968^{* *}$ & 0.759 & $6.401^{* *}$ & $Y=e^{4.208+0.151 X}$ & 282.73 & الفاقد \\
\hline- & $1.651^{-}$ & 0.113 & $-1.285^{-}$ & $Y=20.886-0.228 X$ & 19.06 & نصيب الفرد \\
\hline
\end{tabular}

المصدر : جمعت وحسبت من التحليل الإحصائي للبيانات الواردة بجدول (6). 
جدول 8. الأهمية النسبية للإنتاج والاستهلاك والفائض والعجز من محصول البصل خلال الفترة (2017-2019)

\begin{tabular}{|c|c|c|c|c|c|c|c|c|}
\hline \multicolumn{2}{|c|}{ العجز } & \multicolumn{2}{|c|}{ الفائض } & \multicolumn{2}{|c|}{ الاستهلاك * } & \multicolumn{2}{|c|}{ الإنتاج } & \multirow[b]{2}{*}{ المحافظة } \\
\hline$\%$ & (ألف طمية) & $\%$ & 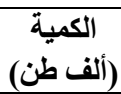 & $\%$ & 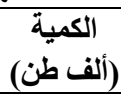 & $\%$ & 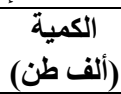 & \\
\hline 14.5 & 94.2 & - & - & 5.4 & 95.7 & 0.1 & 1.5 & الإسكندرية \\
\hline- & - & 4.02 & 67.7 & 6.6 & 115.3 & 6.6 & 182.9 & البحيرة \\
\hline- & - & 40.2 & 676.4 & 5.3 & 92.9 & 27.6 & 769.2 & الغربية \\
\hline 5.5 & 35.9 & - & - & 3.6 & 62.7 & 1.0 & 26.8 & كفر الثيخ \\
\hline - & - & 12.5 & 209.9 & 6.9 & 120.5 & 11.9 & 330.4 & الدقهلية \\
\hline 0.8 & 4.9 & - & - & 1.6 & 27.8 & 0.8 & 22.8 & دمياط \\
\hline - & - & 4.03 & 67.8 & 7.6 & 133.4 & 7.2 & 201.2 & الثرقية \\
\hline 3.1 & 20.0 & - & - & 1.4 & 24.3 & 0.2 & 4.4 & الإسماعيلية \\
\hline 1.7 & 10.8 & - & - & 0.8 & 13.8 & 0.1 & 3.0 & بور سعيد \\
\hline 1.4 & 9.3 & - & - & 0.8 & 13.5 & 0.2 & 4.2 & السويس \\
\hline 10.0 & 64.9 & - & - & 4.6 & 80.0 & 0.5 & 15.2 & المنوفية \\
\hline - & - & 3.9 & 66.1 & 5.9 & 104.5 & 6.1 & 170.6 & القليو بية \\
\hline 27.2 & 176.7 & - & - & 10.1 & 176.7 & 0.0 & 0.0 & القاهرة \\
\hline 64.2 & 416.6 & 64.6 & 1087.7 & 60.4 & 1061.0 & 62.2 & 1732.1 & الوجه البحري \\
\hline 21.0 & 136 & - & - & 9.1 & 160.6 & 0.9 & 24.6 & الجيزة \\
\hline - & - & 5.7 & 96.0 & 3.4 & 59.1 & 5.6 & 155.1 & بني سويف \\
\hline - & - & 5.02 & 84.4 & 3.8 & 67.4 & 5.4 & 151.8 & 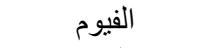 \\
\hline 3.7 & 24.0 & - & - & 5.9 & 103.2 & 2.8 & 79.2 & المنيا \\
\hline 24.7 & 160 & 10.72 & 180.4 & 22.2 & 390.3 & 14.7 & 410.6 & مصر الوسطي \\
\hline 5.9 & 38 & - & - & 4.7 & 82.3 & 1.6 & 44.3 & أسيوط \\
\hline- & - & 9.8 & 164.2 & 5.3 & 93.3 & 9.2 & 257.5 & سو هاج \\
\hline - & - & 0.04 & 0.4 & 3.4 & 59.4 & 2.1 & 59.8 & قنا \\
\hline 2.1 & 13.9 & - & - & 1.3 & 23.3 & 0.3 & 9.4 & الأقصر \\
\hline 1.3 & 8.6 & - & - & 1.6 & 27.6 & 0.7 & 19.0 & أسو ان \\
\hline 9.3 & 60.5 & 9.9 & 164.6 & 16.3 & 285.9 & 13.7 & 380.9 & مصر العليا \\
\hline- & - & 2.23 & 37.6 & 0.3 & 4.5 & 1.5 & 42.1 & الو ادي الجديد \\
\hline 0.3 & 1.9 & - & - & 0.5 & 8.2 & 0.2 & 6.3 & مطروح \\
\hline 1.3 & 8.2 & - & - & 0.5 & 8.4 & 0.0 & 0.2 & شمال سيناء \\
\hline 0.3 & 1.8 & - & - & 0.1 & 1.9 & 0.0 & 0.1 & جنوب سيناء \\
\hline- & - & 12.63 & 212.5 & 0.1 & 1.5 & 7.7 & 214.0 & النوبارية \\
\hline 1.9 & 11.9 & 14.9 & 250.1 & 1.4 & 24.4 & 9.4 & 262.6 & خارج الوادي \\
\hline 100.0 & 649 & 100.0 & 1030.0 & 100 & 1756.3 & 100 & 2786.3 & إجمالي الجمهورية \\
\hline
\end{tabular}

* تم تقديره بتوزيع إجمالي إنتاج البصل للجمهورية على مستوى المحافظات وفقا للأهمية النسبية لعدد السكان لكل محافظة خلال الفترة (2017-2019) مرجح بواسطة

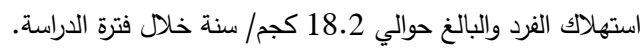

المصدر : جمعت وحسبت من :

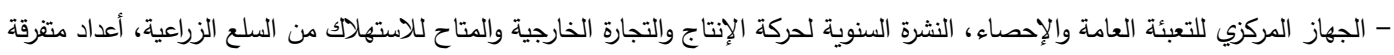

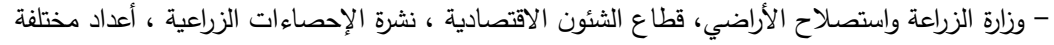

تقدير الفائض والعجز من محصول البصل بمحافظات الوجه البحري أعلى فائض بلغ حوالي 1087.7 ألف طن بنسبة تمثل نحو 64.9\% من إجمالي الفائض موزعة على الفي الجمهورية

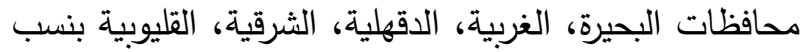
بلغت نحو 4.02\%، 40.2\%، 12.5\%، 4.03\%، على الترتيب في حين تمثل محافظات خارج الوادي ومصر

يتبين من جدول (8) أن إجمالي الفائض لمحصول البصل على مستوى الجمهورية كمتوسط للفترة (2017-

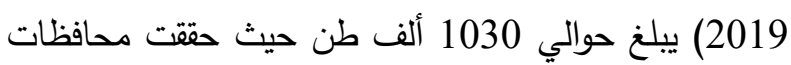


981 فيروز أحمد عبد المالك أحمد وسحر سعيد يعقوب محمد: التوزيع الأمثل لإنتاج محصولي البرتقال والبصل .............

يبلغ حوالي 649 ألف طن حيث يبلغ العجز أقصاه بمحافظات القاهرة، الجيزة، الإسكندرية، المنوفية، كفر الثيخ، أسيوط بكميات عجز تبلغ حوالي 176.7، 176. 136، 94.2، 64.9، 35.9، 38 ألف طن بنسب تمثل 27.2\% 21\% 210\% 14.5\%

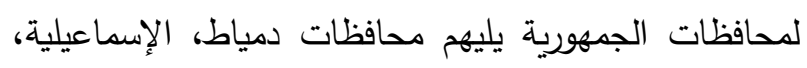

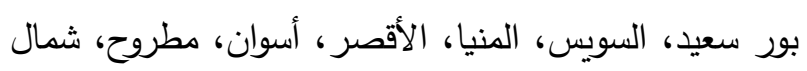
سيناء، جنوب سيناء بكميات عجز تبلغ حوالي 4.9، 20، 10.8، 9.3، 24، 13.9، 8.6، 1.9، 8.2، بنسب تمثل نحو 0.8\%، 3.1\%، 1.7\% \% \% \% \% \% \% \% \% \%

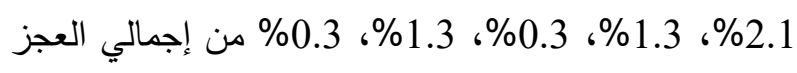
على الترتيب.

نتائج نموذج النقل الأمثل لمحصول البصل بين محافظات

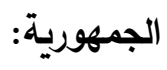

باستعراض خطة النقل المثلى لمحصول البصل بين محافظات الفائض ومحافظات العجز باستخدام النموذج الاقتصادي الرياضي للنقل الوارد بجدول (9) بهدف تدنية

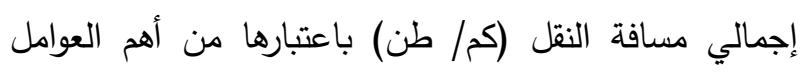
المحددة لتكلفة و زمن نقل الفائض من محصول البصل من ناحية ووصول هذا الفائض الطازج بحالة جيدة وفي الوقت المناسب للمستهلك من ناحية أخرى مما يساعد على تحقيق السعر المناسب لكل من المنتج والمستهلك. ويوضتح جدول (10) نتائج التوزيع الأمثل للفائض من البصل والذي يحقق النهاية الدنيا لإجمالي مسافة نقل البصل من محافظات الفائض والبالغ عددها 11 محافظة وهي

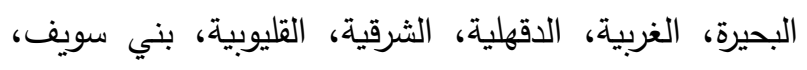
الفيوم، سوهاج، قنا، الوادي الجديد، النوبارية إلى محافظات

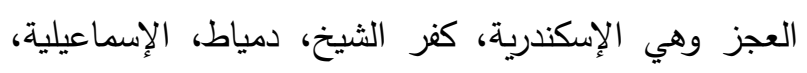

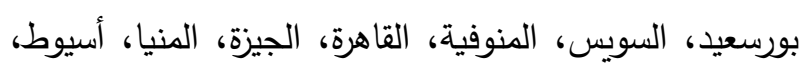
الأقصر ، أسوان، مطروح، شمال سيناء، جنوب سيناء .
الوسطى ومصر العليا نحو 14.9\%، 10.7\%، 9.9\% على الترتيب من متوسط الفائض من البصل خلال فترة الدراسة. كما يتضح من نفس الجدول أن إجمالي العجز الحالي على مستوى الجمهورية في متوسط الفترة (2017-2019) يبلغ حوالي 649 ألف طن حيث يبلغ العجز أقصاه بمحافظات القاهرة، الجيزة، الإسكندرية، المنوفية، كفر الثيخ، أسيوط بكميات عجز تبلغ حوالي 176.7، 136، 94.2،

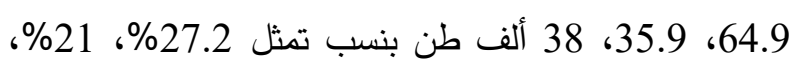
14.5\%، 10\%، 5.5\%، 5.9\% من إجمالي العجز

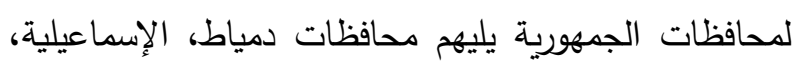
بور سعيد، السوي، المنيا، الأقصر، أسوان، مطروح، شمال سيناء، جنوب سيناء بكميات عجز تبلغ حوالي 4.9، 20، 10.8، 9.3، 24، 13.9، 8.6، 1.9، 8.2، 1.9 ألف طن 1.9 بنسب تمثل نحو 0.8\%، 3.1\%، 1.7\% \% \% \% \% \% \% \% \% \% \%2.1\% 1.3\%، 0.3\%، 1.3\% 0.3 من إجمالي العجز على الترتيب. تقدير الفائض والعجز من محصول البصل بمحافظات الجمهورية يتبين من جدول (8) أن إجمالي الفائض لمحصول البصل على مستوى الجمهورية كمتوسط للفترة (20172019) يبلغ حوالي 1030 ألف طن حيث حققت محافظات الوجه البحري أعلى فائض بلغ حوالي 1087.7 ألف طن بنسبة تمثل نحو 64.9\% من إجمالي الفائض موزعة على بلى

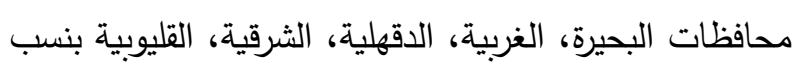
بلغت نحو 4.02\%، 40.2\%، 12.5\%، 4.03\% \% \% على الترتيب في حين تمثل محافظات خارج الوادي ومصر الوسطى ومصر العليا نحو 14.9\%، 10.7\%، 9.9\% على

الترتيب من متوسط الفائض من البصل خلال فترة الدراسة. كما يتضح من نفس الجدول أن إجمالي العجز الحالي على مستوى الجمهورية في متوسط الفترة (2017-2019) 
جدول9. مصفوفة النقل لمحصول البصل بين مناطق العرض والطلب خلال متوسط الفترة ( 2017 - 2019 )

\begin{tabular}{|c|c|c|c|c|c|c|c|c|c|c|c|c|c|c|c|c|c|c|}
\hline $\begin{array}{c}\text { Supply } \\
\text { (ton) }\end{array}$ & سنوبناء & $\begin{array}{l}\text { ش15 } \\
\text { شيناء } \\
\text { سماء }\end{array}$ & $\begin{array}{c}\text { D14 } \\
\text { مطروح }\end{array}$ & $\begin{array}{l}\text { D13 } \\
\text { اسوان }\end{array}$ & $\begin{array}{l}\text { الاقصر } \\
\text { D12 }\end{array}$ & $\begin{array}{c}\text { D11 } \\
\text { اسيوط }\end{array}$ & $\begin{array}{l}\text { المنيا } \\
\text { D10 }\end{array}$ & الجيزة & القاهرة & المنوفية & السويس & $\begin{array}{c}\text { D5 } \\
\text { بورسعيد }\end{array}$ & الاسماعيلية & $\begin{array}{c}\text { D3 } \\
م ي ا ط\end{array}$ & كفريخ الثن & $\begin{array}{c}\text { D1 } \\
\text { الاسكندرية }\end{array}$ & \multicolumn{2}{|c|}{ Destination } \\
\hline 67.69 & 695 & 422 & 365 & 1082 & 853 & 537 & 400 & 178 & 175 & 121 & 302 & 316 & 262 & 255 & 85 & 89 & البحيرة & $\mathrm{S} 1$ \\
\hline 676.38 & 624 & 331 & 479 & 1068 & 838 & 520 & 361 & 124 & 155 & 42 & 211 & 245 & 183 & 100 & 62 & 181 & الغربية & S2 \\
\hline 209.9 & 657 & 369 & 363 & 1097 & 867 & 558 & 424 & 155 & 194 & 120 & 249 & 137 & 183 & 34 & 107 & 267 & الدقهلية & S3 \\
\hline 67.79 & 568 & 239 & 501 & 1031 & 802 & 490 & 408 & 116 & 118 & 95 & 179 & 91 & 86 & 106 & 138 & 285 & الشرقية & S4 \\
\hline 66.07 & 583 & 288 & 465 & 951 & 722 & 423 & 288 & 51 & 97 & 51 & 163 & 205 & 143 & 146 & 132 & 215 & لقليوبية & S5 \\
\hline 96 & 652 & 365 & 405 & 789 & 559 & 251 & 196 & 147 & 157 & 276 & 245 & 315 & 257 & 391 & 356 & 316 & \multicolumn{2}{|c|}{ S6 بني سويف } \\
\hline 84.38 & 655 & 367 & 367 & 865 & 636 & 327 & 202 & 110 & 160 & 198 & 247 & 300 & 242 & 370 & 279 & 278 & الفيوم & S7 \\
\hline 164.16 & 550 & 725 & 780 & 449 & 255 & 190 & 299 & 507 & 517 & 635 & 605 & 675 & 617 & 751 & 716 & 691 & سو هاج & S8 \\
\hline 0.38 & 413 & 804 & 860 & 372 & 143 & 270 & 437 & 584 & 597 & 715 & 593 & 755 & 697 & 831 & 796 & 771 & قنا & S9 \\
\hline 37.61 & 844 & 839 & 1012 & 524 & 331 & 274 & 399 & 624 & 640 & 680 & 720 & 795 & 731 & 875 & 760 & 824 & \multicolumn{2}{|c|}{ S10 الو ادي الجديد } \\
\hline 212.47 & 691 & 400 & 321 & 1052 & 822 & 515 & 370 & 148 & 188 & 142 & 280 & 322 & 265 & 272 & 191 & 63 & \multicolumn{2}{|c|}{ S11 النوبنارية } \\
\hline & 1.82 & 8.14 & 1.92 & 8.53 & 13.92 & 38.10 & 24.02 & 136.08 & 176.7 & 64.86 & 9.34 & 10.8 & 19.98 & 4.93 & 35.87 & 94.20 & \multicolumn{2}{|c|}{ Demand (ton) } \\
\hline
\end{tabular}


جدول 10. التوزيع الأمثل لفائض الإنتاج من البصل بالطن بين مناطق الجمهورية كمتوسط الفترة ( 2017 - 2019 )

\begin{tabular}{|c|c|c|c|c|c|c|c|c|c|c|c|c|c|c|c|c|c|c|}
\hline للتصديرح & $\begin{array}{c}\text { Supply } \\
\text { (ton) }\end{array}$ & سيناء & $\begin{array}{l}\text { شمال } \\
\text { D15 } \\
\text { شيناء }\end{array}$ & $\begin{array}{c}\text { D14 } \\
\text { مطروح }\end{array}$ & $\begin{array}{l}\text { أسوان } \\
\text { D13 }\end{array}$ & $\begin{array}{l}\text { الأقصر } \\
\text { D12 }\end{array}$ & $\begin{array}{c}\text { D11 } \\
\text { أسيوط }\end{array}$ & $\begin{array}{l}\text { D10 } \\
\text { المنيا }\end{array}$ & $\begin{array}{c}\text { D9 } \\
\text { الجيزة }\end{array}$ & $\begin{array}{c}\text { D8 } \\
\text { القاهرة }\end{array}$ & $\begin{array}{c}\text { D7 } \\
\text { المنوفية }\end{array}$ & $\begin{array}{c}\text { D6 } \\
\text { السويس }\end{array}$ & $\begin{array}{c}\text { D5 } \\
\text { بورسيد }\end{array}$ & $\begin{array}{c}\text { D4 } \\
\text { الاسماعيلية }\end{array}$ & $\begin{array}{c}\text { D3 } \\
\text { دمياط }\end{array}$ & $\begin{array}{c}\text { D2 } \\
\text { الثريخ }\end{array}$ & $\begin{array}{c}\text { D1 } \\
\text { الاسكندية }\end{array}$ & Destination \\
\hline 67.69 & 67.69 & & & & & & & & & & & & & & & & & البحيرة \\
\hline 418.51 & 676.38 & & & & & & & & & 147.8 & 64.86 & 9.34 & & & & 35.87 & & الغربية \\
\hline \multirow[t]{3}{*}{204.97} & 209.9 & & & & & & & & & & & & & & 4.93 & & & الاقهلية \\
\hline & 67.79 & & 8.14 & & & & & & & 28.87 & & & 10.8 & 19.98 & & & & S4 الثرقية \\
\hline & 66.07 & & & & & & & & 66.07 & & & & & & & & & S5 القليوبية S5 \\
\hline 71.98 & 96 & & & & & & & 24.02 & & & & & & & & & & S6 بني سويف S6 \\
\hline 14.37 & 84.38 & & & & & & & & 70.01 & & & & & & & & & الفيوم S7 \\
\hline \multirow[t]{2}{*}{102.17} & 164.16 & 1.44 & & & 8.53 & 13.92 & 38.1 & & & & & & & & & & & سوهاج \\
\hline & 0.38 & 0.38 & & & & & & & & & & & & & & & & S9 \\
\hline 37.61 & 37.61 & & & & & & & & & & & & & & & & & S10 الوادي الجليد \\
\hline \multirow[t]{2}{*}{116.35} & 212.47 & & & 1.92 & & & & & & & & & & & & & 94.2 & S11 النوبارية S11 \\
\hline & & 1.82 & 8.14 & 1.92 & 8.53 & 13.92 & 38.1 & 24.02 & 136.08 & 176.7 & 64.86 & 9.34 & 10.8 & 19.98 & 4.93 & 35.87 & 94.2 & Demand (ton) \\
\hline
\end{tabular}


تصدير يقدر بحوالي 14.37 ألف طن يمثل نحو 17\% من جملة الفائض لمحافظة الفيوم، بينما يتم توزيع فائض محافظة سوهاج والبالغ حوالي 164.16 ألف طن إلى محافظات أسيوط، الأقصر، أسوان، جنوب سيناء بكميات تبلغ حوالي 38.1، 13.92، 8.53، 1.44 ألف طن على الترتيب تمثل نحو 23.2\%، 8.5\%، 5.2\%، 0.9\% من جملة الفائض لمحافظة سوهاج على الترتيب، ويتبقى لديها فائض تصدير

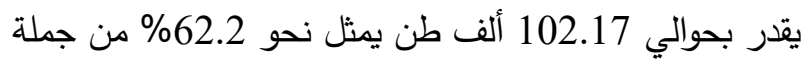
الفائض لمحافظة سوهاج. وأيضا يتم توزيع الفائض لمحافظة قنا والبالغ حوالي 0.38 ألف طن إلى محافظة قنا بنسبة تمثل نحو 100\% من جملة الفائض لمحافظة قنا. بينما يتم توزيع الفائض لمنطقة النوبارية والبالغ حوالي 212.47 ألف طن إلى محافظات الإنكندرية، مطروح بكميات تبلغ حوالي 94.2، 1.92 ألف طن بنسبة تمثل نحو 44.3\%، 0.9\% من جملة الفائض لمنطقة النوبارية ويتبقى لديها فائض للتصدير يقدر بحوالي 116.35 ألف طن يمثل نحو 54.8\% من جملة الفائض لمنطقة النوبارية. وتثير نتائج نموذج النقل أيضاً إلى أنه تم زيادة كمية الصادرات من البصل من 1033.53 1033.53 ألف طن أي بزيادة قدرها 588.86 ألف طن تمثل الفى نحو 57\% من متوسط كمية الصادرات من البصل خلال فترة الدراسة وبالتالي فإن إعادة توزيع البصل بين مناطق لئقل ومحافظات الجمهورية يؤدي إلى زيادة الصادرات وتقليل

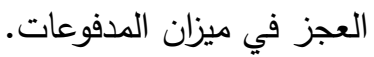

\section{توصيات الدراسة:}

1- إتاحة المعلومات التسويقية المتعلقة بالتوزيع الأمثل لنقل محاصيل تلك الدراسة (البرتقال والبصل) للغرف التجارية

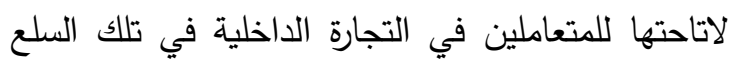
ولإدارة أسواق الجملة لتجارة الخضر والفاكهة، وكنلك لنقط التجارة الخارجية لاتاحتها للمستثمرين والمصدرين للإستفادة منها في إتخاذ قراراتهم التسويقية.
ويتضح من جدول (10) أن نتائج نموذج النقل للبصل تثير إلى عدم توزيع الفائض من البصل لكل من محافظات البحيرة، الوادي الجديد، وتوجيهه فقط للتصدير، بينما يتم

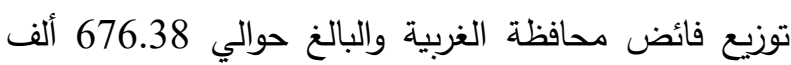
طن إلى محافظات كفر الثيخ، السويس، المنوفية، القاهرة بكميات تبلغ حوالي 35.9، 9.3، 64.9، 147.8 ألف طن على الترتيب تمثل نحو 5.3\%، 1.4\%، 9.6\%؛ 21.9\% من جملة الفائض لدحافظة الغربية على الترتيب ويتبقى لديها فائض تصدير يقدر بحوالي 418.5 ألف طن يمثل نحو 61.9 من جملة الفائض لمحافظة الغربية. بينما يتم توزيع الفائض لكحافظة الدقهلية والبالغ حوالي 209.9 ألف طن إلي محافظة دمياط بكمية تبلغ حوالي 4.9 ألف طن بنسبة تمثل نحو 2.3\% من جملة الفائض لمحافظة الدقهلية ويتبقى لديها فائض تصدير يقدر بحوالي 205 ألف طن يمثل نحو 97.7\% من جملة الفائض لدحافظة الدقهلية. كما يتم توزيع الفائض لمحافظة الشرقية والبالغ حوالي 67.79 ألف طن إلى الى محافظات الإسماعيلية، بورسعيد، القاهرة، شمال سيناء بكمية تبلغ حوالي 19.98، 10.8، 28.87، 8.14 ألف طن بنسب تمثل نحو 29.5\%، 15.9\%، 19.8 \%2.6\%، 12\% على الترتيب من جملة الفائض لمحافظة الثرقية ولا يتبقى لديها فائض للتصدير • وأيضا يتم توزيع الفائض لمحافظة القليوبية والبالغ حوالي 66.07 ألف طن إلى محافظة الجيزة بكمية تبلغ حوالي 66.07 ألف طن بنسبة تمثل نحو 100\% من جملة الفائض لمحافظة القليوبية. كما يتم توزيع فائض محافظة بني سويف والبالغ حوالي 96 ألف طن إلى محافظة

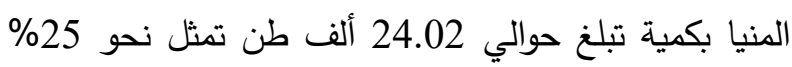
من جملة الفائض لمحافظة بني سويف ويتبقى لديها فائض

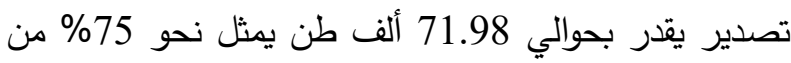
جملة الفائض لمحافظة بني سويف. كما يتم توزيع الفائض لهحافظة الفيوم والبالغ حوالي 84.38 ألف طن إلى محافظة الجيزة بكمية تبلغ حوالي 70.1 ألف طن بنسبة تمثل نحو 83 من جملة الفائض لمحافظة الفيوم ويتبى لديها فائض 
985 فيروز أحمد عبد المالك أحمد وسحر سعيد يعقوب محمد: التوزيع الأمثل لإنتاج محصولي البرتقال والبصل ............

عمرو سعيد علي الشافعي، تحليل اقتصادي لكفاءة أداء أسواق الجملة لتجارة الخضر والفاكهة في جمهورية مصر العربية، رسالة دكتوراه، قسم الاقتصاد والإرشاد الزراعي والتتمية الريفية، كلية الزراعة، جامعة دمنهور،

محمد ماضي علة داوود سليمان، تسويق البرتقال في

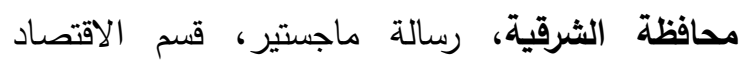
الزراعي، كلية الزراعة، جامعة الزقازيق، 2017.

محي زين العابدين محمد درويش، دراسة اقتصادية تحليلية لإنتاج واستهلاك محصول البصل في مصر مع الإثارة إلى الكفاءة التسويقية، المجلة المصرية للاقتصاد الزراعي، المجلد السابع والعشرون، العدد الرابع، ديسمبر .2017

وزارة الزراعة واستصلاح الأراضي، مركز البحوث الزراعية، استراتيجية التنمية الزراعية المستدامة 2030الصادرة التردية عام 2000.

وزارة الزراعة واستصلاح الأراضي، قطاع الشئون الاقتصادية، نشرة الميزان الغذائي، أعداد مختلفة وراعة العافية

وزارة الزراعة واستصلاح الأراضي، قطاع الثئون الاقتصادية، نشرة الإحصاءات الزراعية، أعداد مختلفة.

www.distancesfrom.com

Bindu Choudhary, (2016). Optimal Solution of Transportation Problem Based on Revised Distribution Method. International Journal of Innovative Research in Science, Engineering and Technology, Vol. 5, Issue 8.

Abdallah A. Hlayel and Mohammad A. Alia, 2012. Solving transportation Problems Using the Best Candidates Method. Computer Science \& Engineering: An International Journal (CSEIJ), Vol.2, No.5.
2- ضرورة استتاد أجهزة الإرشاد الزراعي عند تنفيذها للبرامج

الإرشادية الخاصة بتبني زراع محاصيل الدراسة للمعاملات الزراعية التي ترفع من الكفاءة التصديرية وتقلل من الفاقد الإنتاجي والتسويقي إلى نتائج هذه الدراسة للتعرف على الأهمية النسبية للمحافظات ذات الفائض التصديري التي يمكن أن ينفذ بها تلك البرامج. 3- استتاداً إلى ما أوضحته نتائج الدراسة من كبر كمية الفائض عن حاجة الاستهلاك المحلي من البرتقال بمحافظتي البحيرة والإسماعيلية ومنطقة النوبارية وكذلك كبر كمية الفائض عن حاجة الاستهلاك المحلي من البصل بمحافظتي الغربية والدقهلية فإنه يجب أن تعطى الأولوية لإقامة محطات فرز وتعبئة محاصيل الخضر والفاكهة بتلك المناطق وبصفة خاصة منطقة النوبارية لاستيعاب التوسع في إنتاج تلك المحاصيل لأغراض - التصدير 4- ضرورة استتاد الهيئات التسويقية وجمعيات النقل بالسيارات عند تحديد تعريفة وتكاليف نقل السلع الزراعية إلى نتائج هذه الدراسة.

\section{المراجح}

الجهاز المركزي للتعبئة العامة والإحصاء، النشرة السنوية لحركة الإنتاج والتجارة الخارجية والمتاح للاستهلاك من السلع الزراعية، أعداد مختلفة.

السيد السيد جاد عبد الرحمن، أثر رفع أسعار الوقود على تكاليف إنتاج بعض المحاصيل الزراعية بمحافظة الثرقية ، المجلة المصرية للاقتصاد الزراعي، المجلد الرابع والعشرون ، العدد الرابع(ب) ، ديسمبر 2014. 


\title{
Optimum Distribution of Orange and Onion Crops Among the Egyptian Governorates Using the Transport Models
}

\author{
Fayrouz. A. A. Ahmed and Sahar.S.Y.Mohamed
}

The research mainly aimed at minimizing transport costs for orange and onion crops by reducing transportation distances between production areas and areas of consumption or export in order to reduce their marketing costs in order to increase their farm prices and reduce their consumer prices in addition to reducing their export costs based on the results of the transport model through the programming method Linear.

It is evident from the results of the optimal distribution of the surplus oranges, which achieves the lower end of the total distance to transport oranges from the surplus governorates, which are 13 governorates, which are Buhaira, Gharbia, Kafr El Sheikh, Sharkia, Ismailia, Suez, Menoufia, Qalyubia, Assiut, New Valley, Matrouh, North Sinai , Nubaria to the governorates of Alexandria, Dakahlia, Damietta, Port Said, Cairo, Giza, Beni Suef, Fayoum, Minya, Sohag, Qena, Luxor, Aswan, and South Sinai.

It is also evident from the results of the transportation model for oranges that the surplus of oranges is not distributed to the governorates of Beheira, Kafr El Sheikh, Sharkia, and Matrouh and directed only for export, while the surplus of the Gharbia Governorate, which is about 75.5 thousand tons, is distributed to the governorates of Dakahlia and Damietta in quantities of about 22.4 and 12.6 thousand tons, respectively, which represents about $29.7 \%$ and $16.7 \%$ of the total surplus of Al-Gharbia Governorate, respectively.

It has an export surplus of about 40.5 thousand tons, which represents about $53.6 \%$ of the total surplus of Al-Gharbia Governorate. While the surplus is distributed to Ismailia Governorate, amounting to about 454.5 thousand tons, to Port Said Governorate, in an amount of about 6.2 thousand tons, representing about $1.4 \%$ of the total surplus of Ismailia Governorate, leaving it with an export surplus estimated at about 448.3 thousand tons, representing about $98-6 \%$ of the total surplus for Ismailia Governorate. The surplus is distributed to Suez Governorate, which is about 21.5 thousand tons, to South Sinai, in an amount of about 0.4 thousand tons, representing about $1.9 \%$ of the total surplus of the Suez Governorate, and it has an export surplus of about 21.1 thousand tons, which represents about $98.1 \%$ of the total surplus for Suez Governorate. Also, the surplus is distributed to Menoufia Governorate, amounting to about 170.2 thousand tons, to Qena Governorate, in an amount of about 14.9 thousand tons, representing about $8.8 \%$ of the total surplus of Menoufia Governorate, and it remains with an export surplus estimated at about 155.3 thousand tons, representing about $91: 2 \%$ of the total surplus for Menoufia Governorate. The surplus of Qalyubia governorate, amounting to about 262.6 thousand tons, is distributed to the governorates of Cairo, Giza, Beni Suef, Fayoum and Minya, in quantities of about 79.7, $30,6.1,26,40.3$ thousand tons, respectively, representing about $30.4 \%, 11.4 \%, 2.3 \%, 9.9 \%$ and $15.3 \%$ of the total surplus for Qalyubia Governorate respectively, and it has an export surplus of about 80.5 thousand tons, representing about $30.7 \%$ of the total surplus. To Qalyoubia Governorate. The surplus in Assiut Governorate, which is about 44.6 thousand tons, is distributed to the governorates of Sohag and Qena, in quantities of about 33 and 11.6 thousand tons, respectively, at a rate of about $74 \%$ and $26 \%$ for each of them, respectively, of the total surplus of Assiut Governorate, while the Distributing the surplus of the New Valley Governorate, amounting to about 20.3 thousand tons, to the governorates of Sohag, Luxor and Aswan, in quantities of about 1.3, 9.5, and 9.5 thousand tons, respectively, representing about $6.4 \%, 46.8 \%$ and $468 \%$ of the total surplus for the New Valley Governorate, respectively. Also, the surplus is distributed to North Sinai Governorate, amounting to about 0.1 thousand tons, to South Sinai Governorate, in an amount of about 0.1 thousand tons, representing about $100 \%$ of the total surplus of North Sinai Governorate.

While the surplus is distributed to the Nubaria region, amounting to about 723,6 thousand tons, to the governorate of Alexandria in an amount of about 36,6 thousand tons, representing about $5.1 \%$ of the total surplus of the Nubaria region, leaving it with an export surplus estimated at about 687 thousand tons, representing about $94.9 \%$ Of the total surplus for the Nubaria region. The results of the transport model also indicate that the quantity of orange exports was increased from 1647 thousand tons to about 2.33 million tons, an increase of 683 thousand tons, representing about $41.5 \%$ of the average quantity of orange exports during the study period, and thus the redistribution of oranges.

Between regions and governorates of the republic, it leads to less waste, as well as an increase in exports and a reduction in the balance of payments deficit. The 


$$
\text { فيروز أحمد عبد المالك أحمد وسحر سعيد يعقوب محمد: التوزيع الأمثل لإنتاج محصولي البرتقال والبصل ........... }
$$

results of the optimal distribution of onion surplus, which achieves the lower end of the total distance of onion transportation from the surplus governorates, amounting to 11 governorates, which are Buhaira, Gharbia, Dakahlia, Sharqia, Qalyubia, Beni Suef, Fayoum, Sohag, Qena, New Valley, Nubaria to the governorates of the surplus which is Alexandria , Kafr El Sheikh, Damietta, Ismailia, Port Said, Suez, Menoufia, Cairo, Giza, Minya, Assiut, Luxor, Aswan, Matrouh, North Sinai, South Sinai. It is clear from the results of the transportation model for onions that the surplus of onions is not distributed to each of the governorates of Beheira and New Valley, and is directed only for export, while the surplus of the Gharbia Governorate, amounting to about 676.38 thousand tons, is distributed to the governorates of Kafr El Sheikh, Suez, Menoufia and Cairo in quantities of About 35.9, 9.4, 64.9 and 147.8 thousand tons, respectively, representing about $5.3 \%, 1.4 \%, 9.6 \%$, and $21.9 \%$ of the total surplus of Al-Gharbia Governorate, respectively, and it is left with An export surplus is estimated at 418.4 thousand tons, representing about $61.9 \%$ of the total surplus for the Gharbia Governorate. While the surplus is distributed to Dakahlia Governorate, amounting to about 209.9 thousand tons, to Damietta Governorate, in an amount of about 4.9 thousand tons, representing about $2.3 \%$ of the total surplus of Dakahlia Governorate, leaving it with an export surplus of about 205 thousand tons, representing about $97.7 \%$ Of the total surplus for Dakahlia Governorate.

The surplus is distributed to Sharkia governorate, amounting to about 67.79 thousand tons, to the governorates of Ismailia, Port Said, Cairo and North Sinai, in an amount of about 19.98, 10.8, 28.9, 8.14 thousand tons, at rates that represent about $29.5 \%$. And $15.9 \%, 42.6 \%$ and $12 \%$, respectively, of the total surplus for the Sharqia Governorate, and it has no remaining surplus for export.

Key words: optimal distribution, surplus and deficit, orange and onion yields, transfer model. 